\title{
PATRÍCIA DE OLIVEIRA ESMERINI
}

Ocorrência e isolamento de Toxoplasma gondii e Neospora spp. em equídeos do Brasil

São Paulo 


\section{PATRÍCIA DE OLIVEIRA ESMERINI}

\section{Ocorrência e isolamento de Toxoplasma gondii e Neospora spp. em equídeos do Brasil}

Tese apresentada ao Programa de Pós-Graduação em Epidemiologia Experimental Aplicada as Zoonoses da Faculdade de Medicina Veterinária e Zootecnia da Universidade de São Paulo, para obtenção do título de Doutor em Ciências

Departamento:

Medicina Veterinária Preventiva e Saúde Animal

Área de Concentração:

Epidemiologia Experimental Aplicada às Zoonoses

Orientadora:

Prof. Dra. Solange Maria Gennari

São Paulo

2012 
Autorizo a reprodução parcial ou total desta obra, para fins acadêmicos, desde que citada a fonte.

DADOS INTERNACIONAIS DE CATALOGAÇÃO-NA-PUBLICAÇÃO

(Biblioteca Virginie Buff D’Ápice da Faculdade de Medicina Veterinária e Zootecnia da Universidade de São Paulo)

T.2466 Esmerini, Patrícia de Oliveira

FMVZ Ocorrência e isolamento de Toxoplasma gondii e Neospora spp. em equídeos do Brasil / Patrícia de Oliveira Esmerini. -- 2012.

$89 \mathrm{f}$ : : il.

Tese (Doutorado) - Universidade de São Paulo. Faculdade de Medicina Veterinária e Zootecnia. Departamento de Medicina Veterinária Preventiva e Saúde Animal, São Paulo, 2013.

Programa de Pós-Graduação: Epidemiologia Experimental Aplicada às Zoonoses.

Área de concentração: Epidemiologia Experimental Aplicada às Zoonoses.

Orientador: Profa. Dra. Solange Maria Gennari.

1. Toxoplasma gondii. 2. Neospora spp. 3. Equídeos. 4. Sorologia. 5. Genotipagem. 6. PCR-RFLP. I. Título. 
UNIVERSIDADE DE SÃO PAULO

FACUIDADE DE MEDICINA VETERINÁRIA E ZOOTECNIA

\section{Comissão de Ética no uso de animais}

\section{CERTIFICADO}

Certificamos que o Projeto intitulado "Ocorrência e isolamento de Toxoplasma gondii e Neospora spp. em eqüídeos", protocolado sob o n $2257 / 2011$, utilizando 400 (quatrocentos) camundongos, sob a responsabilidade da Profa. Dra. Solange Maria Gennari, está de acordo com os princípios éticos de experimentação animal da "Comissão de Ética no uso de animais" da Faculdade de Medicina Veterinária e Zootecnia da Universidade de São Paulo e foi aprovado em reunião de $22 / 6 / 2011$.

We certify that the Research "Occurrence and isolation of Toxoplasma gondii and Neospora spp em equides", protocol number 2257/2011, utilizing 400 (four hundred) mice, under the responsibility Profa. Dra. Solange Maria Gennari, agree with Ethical Principles in Animal Research adopted by "Ethic Committee in the use of animals" of the School of Veterinary Medicine and Animal Science of University of São Paulo and was approved in the meeting of day 06/22/2011.

São Paulo, 18 de julho de 2011.

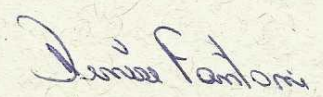

Profa. Dra. Denise Tabacchi Fantoni

Presidente 
Autor: ESMERINI, Patrícia de Oliveira

Título: Ocorrência e isolamento de Toxoplasma gondii e Neospora spp. em equídeos do Brasil

Tese apresentada ao Programa de Pós-Graduação em Epidemiologia Experimental Aplicada às Zoonoses da Faculdade de Medicina Veterinária e Zootecnia da Universidade de São Paulo para obtenção do título de Doutor em Ciências

Data:

Banca Examinadora

Prof. Dr.

Instituição Julgamento

Prof. Dr.

Instituição Julgamento

Prof. Dr.

Instituição Julgamento

Prof. Dr. Instituição Julgamento

Prof. Dr. Instituição Julgamento 
DEDICATÓRLA

"OS DOIS TESTES MAIS DUROS NO CAMHNHO ESPIRITUAL SAOO A PACIÊNCLA PARA ESPERAR O MOMENTO CERTO E A CORAGEM DE NÃO NOS DECEPCIONAR COM O QUE ENCONTRAMOS". PAULO COELHO

AOS MEUS PALS, MARCOS E LORI POR TEREM ME DADO A OPORTUNIDADE DE REALIZAR ESSE MEU GRANDE SONHO E PELO CARINHO NESSA EMPREITADA.

AO MEU GRANDE COMPANHEIRO RAFAEL, QUE ESTEVE AO MEU LADO DESDE O INICIO, SEMPRE COM MUITA PACIEACLA, CARLIHO E AMOR.

AO MEU IRMÃO PELO APOIO NESSE MOMENTO. AOS MEUS ANMAIS QUE SEMPRE FICARAM AO MEU LADO, DANDO MUITA ALEGRLA E AMOR NESSE PERIODO DIFICIL. 


\section{AGRADECIMENTOS}

Agradeço a todas as pessoas que participaram da realização deste trabalho de forma direta e indireta.

À Professora Solange pela paciência, amizade e pela oportunidade de realização deste sonho.

Ao Renato Caravieri pela bondade, amizade e por estar sempre disposto a ajudar.

Ao Sérgio Netto Vitaliano, Aline Diniz Cabral, Maurício C. Horta, Herbert S. Soares, Marcos Gomes Lopes e Eduardo Faria pela ajuda na coleta das amostras.

À Dra. Hilda Fátima de Jesus Pena pela paciência e lições ensinadas durante este período.

À Eliana Villalobos pela ajuda e paciência para execução das PCRs.

Ao Departamento de Medicina Veterinária Preventiva e Saúde Animal da Faculdade de Medicina Veterinária e Zootecnia da Universidade de São Paulo (VPS-FMVZUSP) pelo acolhimento. 
Aos professores do curso da pós-graduação em Epidemiologia Experimental e Aplicada às Zoonoses pelos ensinamentos.

Ao Conselho Nacional de Desenvolvimento Científico e Tecnológico (CNPq) pela concessão da bolsa de Doutorado.

À Deus por ter me proporcionado tudo isso 
"Posso ter defeitos, viver ansioso e ficar irritado algumas vezes, mas não esqueço de que minha vida é a maior empresa do mundo. E que posso evitar que ela vá à falência.

Ser feliz é reconhecer que vale a pena viver, apesar de todos os desafios, incompreensões e períodos de crise.

Ser feliz é deixar de ser vítima dos problemas e se tornar autor da própria história. É atravessar desertos fora de si, mas ser capaz de encontrar um oásis no recôndito da sua alma.

É agradecer a Deus a cada manhã pelo milagre da vida. Ser feliz é não ter medo dos próprios sentimentos. É saber falar de si mesmo. É ter coragem para ouvir um "não". É ter segurança para receber uma crítica, mesmo que injusta". 


\section{RESUMO}

ESMERINI, P. O. Ocorrência e isolamento de Toxoplasma gondii e Neospora spp. em equídeos do Brasil. [Occurrence and Isolation of Toxoplasma gondii and Neospora spp. in equids from Brazil]. 2013. 89 f. Tese (Doutorado em Ciências) Faculdade de Medicina Veterinária e Zootecnia, Universidade de São Paulo, São Paulo, 2012.

Neospora caninum é um parasito intracelular obrigatório, formador de cistos, que acomete vários animais domésticos e silvestres, tendo maior importância nas espécies canina e bovina, nas quais causa problemas nervosos e reprodutivos. Os canídeos do gênero Canis são os únicos reconhecidos como hospedeiros definitivos do $N$. caninum até o momento, nos quais ocorre a fase sexuada de multiplicação, resultando na eliminação de oocistos pelas fezes. Toxoplasma gondii também é um coccídio responsável por uma das zoonoses de maior importância e ocorrência em todo o mundo. A fase assexuada de desenvolvimento do $T$. gondii ocorre nos mamíferos e aves (hospedeiros intermediários) com formação de cistos teciduais e a fase sexuada de desenvolvimento ocorre no intestino delgado dos hospedeiros definitivos, que são os membros da família Felidae. Este estudo teve por objetivo determinar a soroprevalência de anticorpos contra Neospora spp. e T. gondii em equídeos de diferentes regiões do Brasil e o isolamento e caracterização genética destes coccídios em amostras de tecidos de equídeos. A sorologia para $T$. gondii e Neospora spp. foi realizada em 453 amostras de soros por meio da Reação de Imunofluorescência Indireta com ponto de corte de 50 para Neospora spp e 64 para T. gondii. Deste total, oito (1,75\%) amostras (sete de jumentos e um de cavalo) foram positivas para Neospora spp. e 129 (28,47\%) amostras (82 jumentos, 32 cavalos e 15 mulas) para $T$. gondii. Para o isolamento do $T$. gondii foram realizados 29 bioensaios em camundongos, sendo 19 de animais soropositivos e 10 de pools 
de tecidos de cavalos soronegativos. Por meio dessa prova biológica, foi possível o isolamento em uma amostra de jumento (Equus asinus) de Mossoró, RN, ocorrendo a morte dos dois únicos camundongos infectados, no $16^{\circ}$ e $17^{\circ}$ dia pós-inoculação. A caracterização genotípica do isolado foi realizada pela PCR-RFLP utilizando 12 marcadores genotípicos. A genotipagem dessa amostra evidenciou o genótipo \#60 TgCkBr220, já isolado em galinha do Arquipélago de Fernando de Noronha, PE, Brasil. O isolamento de Neospora spp em gerbilos não pode ser feito uma vez que não foi possível a obtenção de tecidos dos equídeos soropositivos.

Palavras-chave: Toxoplasma gondii. Neospora spp. Equídeos. Sorologia. Genotipagem. PCR-RFLP. 


\section{ABSTRACT}

ESMERINI, P. O. Occurrence and isolation of Toxoplasma gondii and Neospora spp. in equids from Brazil. [Ocorrência e isolamento de Toxoplasma gondii e Neospora spp. em equídeos do Brasill.2013 89 f. Tese (Doutorado em Ciências) Faculdade de Medicina Veterinária e Zootecnia, Universidade de São Paulo, São Paulo, 2012.

Neospora caninum is an obligate intracellular parasite, forming cysts that affect many domestic and wild animals, having greater importance in canine and bovine species due neurological and reproductive problems. Canids of the genus Canis are recognized as the only definitive hosts of $N$. caninum until the moment in which sexual phase occurs multiplication, resulting in the elimination of oocysts in the feces. Toxoplasma gondii is also a coccidian parasite responsible for a zoonotic disease of great importance and occurrence around the world. The asexual developmental stage of $T$. gondii occurs in mammals and birds, the intermediate hosts, resulting in the formation of cysts and the sexual stage occurs in the small intestine of definitive hosts, which are the felids, occurring oocysts formation. This study aimed to determine the seroprevalence of antibodies against Neospora spp. and Toxoplasma gondii in equids from different regions of Brazil and the isolation and genetic characterization of these parasites from equids tissue. Serology for $T$. gondii and Neospora spp. was performed in 453 serum samples by Immunofluorescence Antibody Test (IFAT). Of this total, eight (1.75\%) samples (seven of donkeys and one of horse) were positive to Neospora spp. antibodies and 129 (28.47\%) samples (82 donkeys, 32 horses, 15 mules) were $T$. gondii seropositive. For the isolation of $T$. gondii, bioassay was performed in mice. A sample of one donkey (Equus asinus) from Mossoró, RN, was obtained with two of the 20 inoculated mouse infected. The mouse died at day $16^{\text {th }}$ and $17^{\text {th }}$ post inoculation. The genotypic characterization of 
the isolate was performed by PCR-RFLP using 12 genotypic markers. Genotyping showed the genotype \#60 TgCkBr220, already described in chickens from Fernando de Noronha, PE, Brazil. Due the impossibility of acquisition of tissue from Neospora spp seropositive equids, isolation of this coccidian by gerbil bioassay was not possible to be done.

Keywords: Toxoplasma gondii. Neospora spp. Equines. Serology. Genotyping. PCRRFLP. 


\section{LISTA DE FIGURAS}

Figura 1 - Ciclo Biológico do Neospora caninum ........................................... 23

Figura 2 - Ciclo Biológico do Toxoplasma gondii.......................................... 31

Figura 3 - Mapa do Brasil com a localização dos estados e municípios de procedência das amostras e quantidade

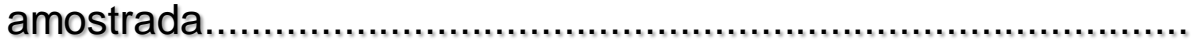




\section{LISTA DE QUADROS}

Quadro 1 - Relação dos estudos de pesquisa de anticorpos anti-Toxoplasma gondii realizados no Brasil com equídeos.

Quadro 2 - Número de amostras de soros coletadas de equídeos, por município e estado.

Quadro 3 - Distribuição do número de camundongos por tecidos de equídeos e identificação das espécies analisadas.

Quadro 4 - Sequência de primers utilizados nas reações de PCR e nested PCR- ITS1 para identificação de protozoários da família Toxoplasmatinae.

Quadro 5 - Informações referentes aos marcadores genéticos e às endonucleases utilizadas na PCR/RFLP.

Quadro 6 - Amostras de referência de Toxoplasma gondii utilizadas como controle positivo da reação de PCR/RFLP 


\section{LISTA DE TABELAS}

Tabela 1 - Número de amostras positivas para anticorpos anti- Neospora spp. (RIFI $\geq 50)$ segundo local de procedência, título de anticorpos e espécie examinada.

Tabela 2 - Número de amostras positivas para anticorpos anti- T. gondi (RIFI $\geq 64)$ segundo titulação, local de procedência e espécie examinada

Tabela 3 - Número de animais examinados e positivos para anticorpos anti$T$. gondii e anti- $N$. caninum por espécie examinada

Tabela 4 - Genótipos multilocus do isolado da amostra primária de jumento do Brasil obtidos pela PCR/RFLP. 


\section{LISTA DE GRÁFICOS}

Gráfico 1 - Frequência de amostras positivas por espécie animal para anticorpos anti-Neospora spp. segundo município de origem dos animais.

Gráfico 2 - Frequência de amostras positivas para anticorpos anti-T. gondii segundo município e espécie animal examinada.

Gráfico 3 - Frequência de animais positivos para anticorpos anti- $T$. gondii e anti- Neospora spp por espécie. 


\section{LISTA DE ABREVIATURAS E SIGLAS}

$\mu g$

micrograma

dATP

desoxiadenosina trifosfatada

dCTP

desoxicitidina trifosfatada

dGTP

desoxiguanosina trifosfatada

DNA

ácido desoxirribonucleico

dNTP

desoxirribonucleotídeos fosfatados

dTTP

desoxitimidina trifosfatada

EDTA

ácido dietilenodiaminotetracético

EPM

Mieloencefalite Protozoária Equina

EUA

Estados Unidos da América

$g$

aceleração da gravidade terrestre

$\mathrm{HCl}$

ácido clorídrico

$\lg G$

Imunoglobulina G

$\mathrm{KCl}$

cloreto de potássio

M

molar

$M G$

Minas Gerais 


\begin{tabular}{|c|c|}
\hline $\mathrm{MgCl}_{2}$ & cloreto de magnésio \\
\hline $\min$ & minutos \\
\hline $\mathrm{mM}$ & milimolar \\
\hline $\mathrm{Na}_{2} \mathrm{CO}_{3}$ & carbonato de cálcio \\
\hline $\mathrm{NaCl}$ & cloreto de sódio \\
\hline $\mathrm{NaHCO}_{3}$ & bicarbonato de sódio \\
\hline NAT & Neospora Agglutination Test \\
\hline $\mathrm{n}-\mathrm{PCR}$ & nested-PCR \\
\hline P.I. & pós-inoculação \\
\hline PCR & polymerase chain reaction \\
\hline $\mathrm{pH}$ & potencial hidrogeniônico \\
\hline RFLP & restriction fragmente length polymorphism \\
\hline RIFI & Reação de Imunofluorescência Indireta \\
\hline rpm & Rotações por minuto \\
\hline seg & segundos \\
\hline SNC & Sistema Nervoso Central \\
\hline TE & tris-HCl + EDTA \\
\hline$v$ & volume \\
\hline
\end{tabular}




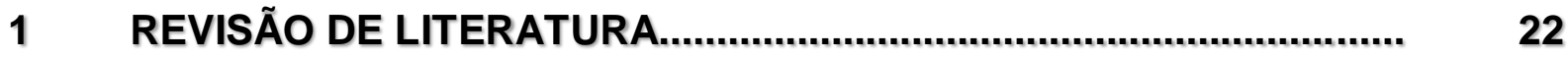

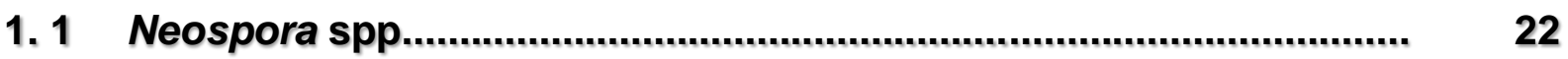

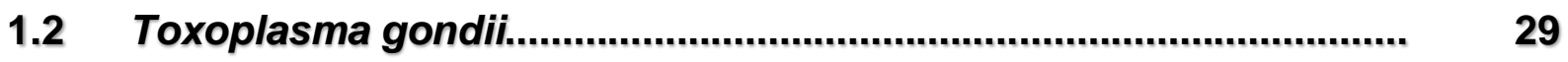

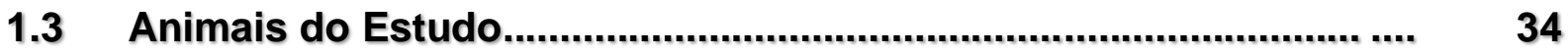

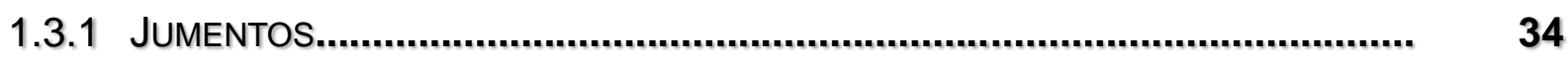

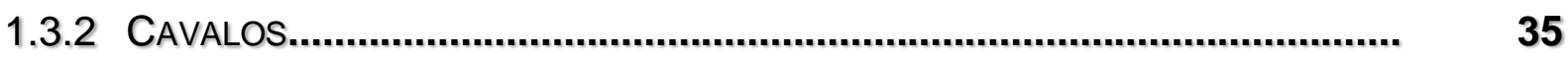

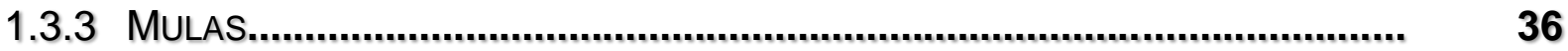

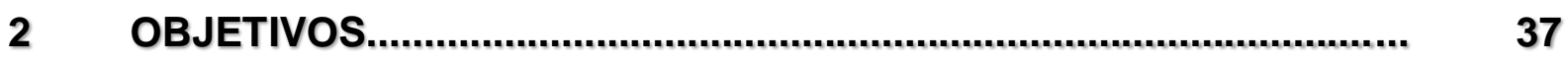

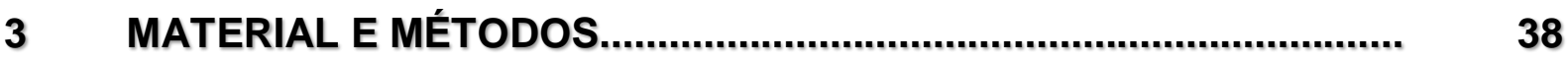

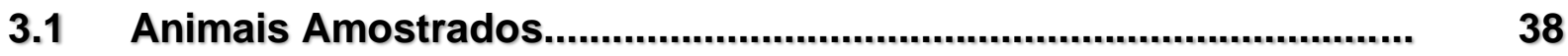

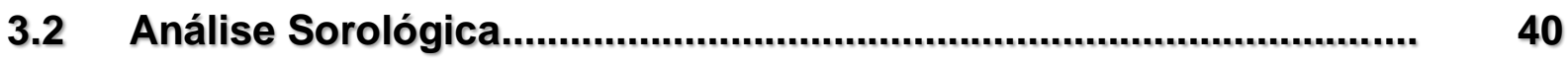

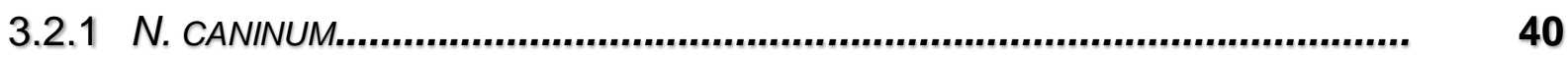

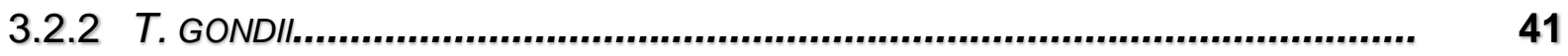

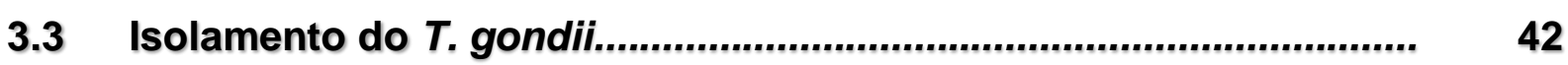

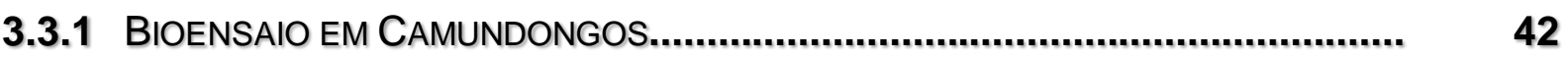

3.4 Identificação Molecular dos Protozoários.......................................... 46

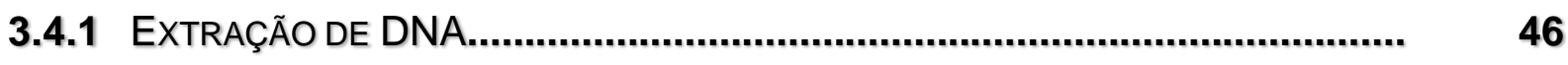

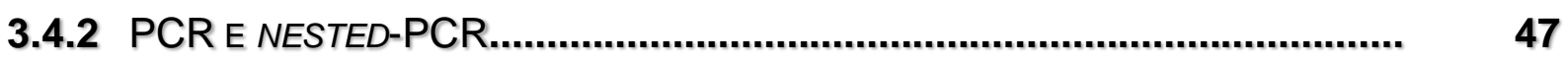

3.5 Caracterização Genética dos Isolados de Toxoplasma gondii........ 49

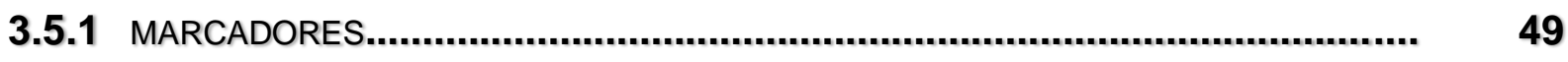

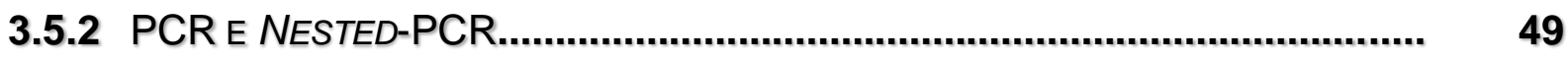

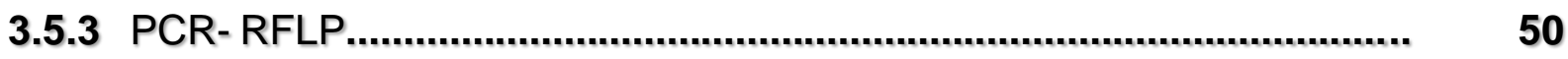

3.6 Análise Estatística..................................................................

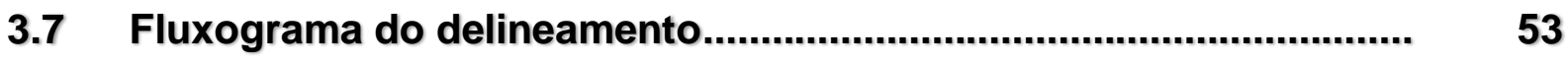

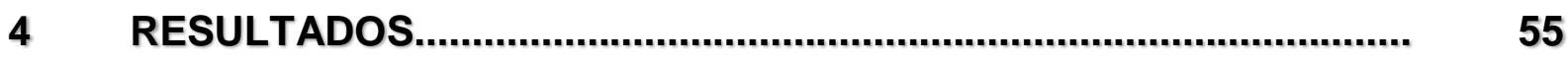




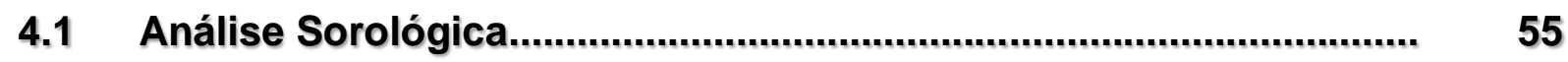

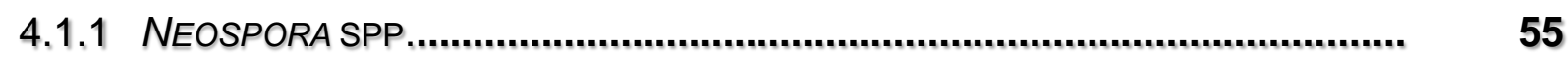

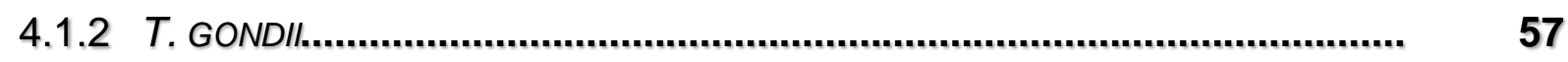

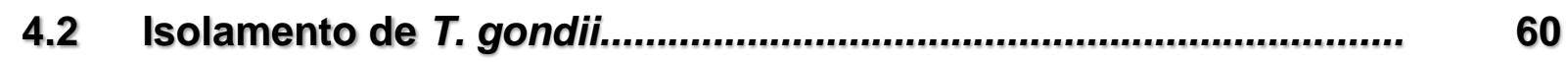

4.3 Análise Molecular das Amostras Primárias....................................... 61

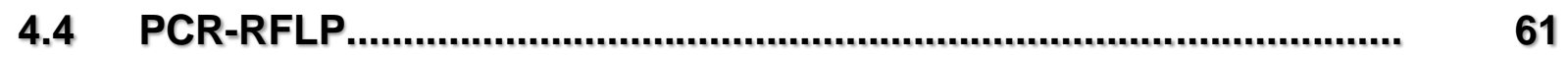

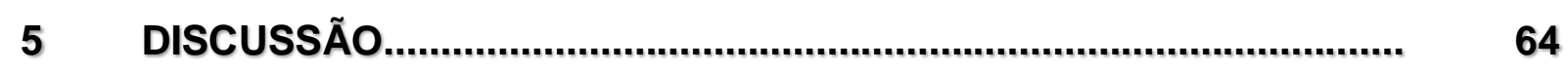

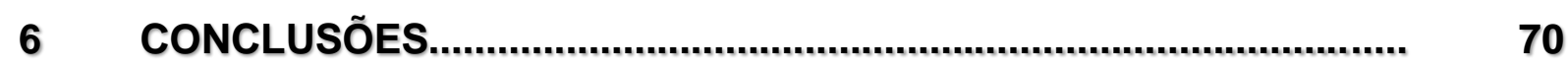

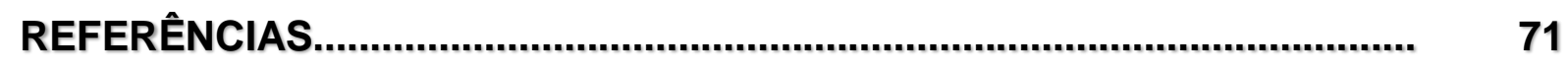

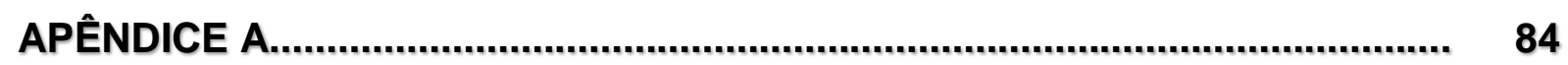




\section{REVISÃO DE LITERATURA}

\section{$1.1 \quad$ Neospora spp.}

Neospora caninum é um parasito intracelular obrigatório, formador de cistos, pertencente ao filo Apicomplexa, causador da doença conhecida como neosporose. Este coccídio acomete vários animais domésticos e silvestres, tendo maior importância nas espécies canina e bovina (DUBEY et al., 1988a),

Em 1988, foi reconhecido como nova espécie e gênero (DUBEY et al., 1988a), entretanto foi primeiramente encontrado em 1984, na Noruega. Cães foram diagnosticados com uma doença neurológica, com quadro semelhante à toxoplasmose e taquizoítos estavam presentes no cérebro e músculos, anticorpos anti-Toxoplasma gondii não foram detectados no soro destes cães, os quais tampouco responderam ao bioensaio em camundongos (BJERKAS; MOHN; PRESTHUS, 1984).

Dubey et al. (1988a) realizaram um estudo retrospectivo (lâminas de tecidos de cães do período de 1948 a 1987), examinando cortes histológicos de 23 cães pela imuno-histoquímica, cuja suspeita da causa da morte era toxoplasmose; em 13 identificou-se T. gondii e nos outros dez cortes, foi encontrado um parasito distinto morfológica e antigenicamente de $T$. gondii que foi classificado, posteriormente, como N. caninum.

O primeiro isolado desse coccídio foi obtido nos Estados Unidos, em cães (DUBEY et al., 1988b), o que levou o agente a ser nomeado Neospora caninum. 
Alguns anos mais tarde verificou-se que esse parasito causava, em cães, uma forma clínica mais severa do que a causada pelo $T$. gondii e foram constatadas diferenças estruturais e histopatológicas entre ambos (DUBEY; LINDSAY, 1993).

Os canídeos do gênero Canis são os únicos reconhecidos como hospedeiros definitivos do $N$. caninum até o momento, nos quais ocorre a fase sexuada de multiplicação, resultando na eliminação dos oocistos pelas fezes. Estes se infectam ingerindo tecidos de bovinos e de outras espécies que contenham cistos teciduais e via transplacentária (transmissão vertical). Os oocistos eliminados com as fezes contaminam água e alimentos consumidos pelos hospedeiros intermediários, dentre os quais os equinos (MCALLISTER et al., 1998; LINDSAY; DUBEY; DUNCAN, 1999). A figura 1 ilustra o ciclo biológico de N. caninum.

Figura 1- Ciclo Biológico de Neospora caninum

Fonte: (SOARES; GENNARI, 2012). ${ }^{1}$

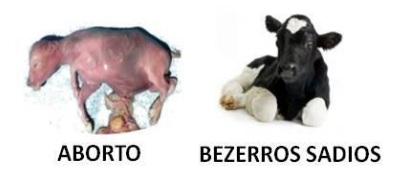

4

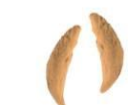

TAQUIZOITOS

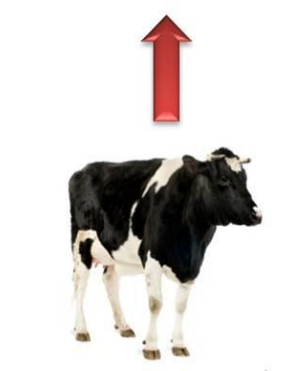

HOSPEDEIROINTERMEDIÁRIO

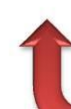

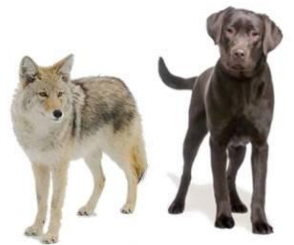

HOSPEDEIROS DEFINITIVOS
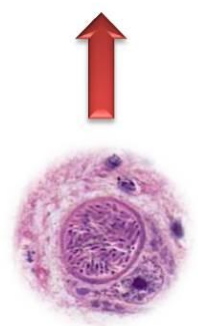

CISTOS TECIDUAIS

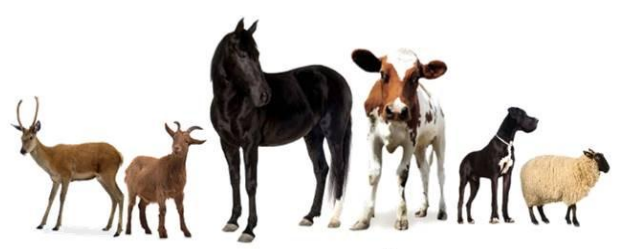

HOSPEDEIROS INTERMEDIÁRIOS

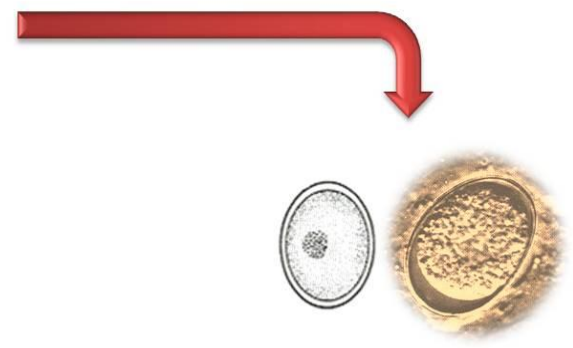

OOCISTOS NÃO ESPORULADOS

NAS FEZES
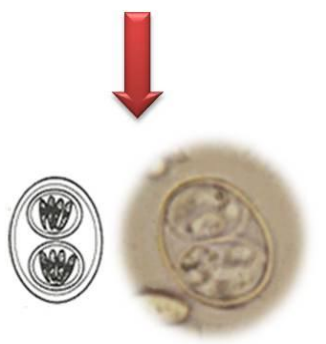

OOCISTOS ESPORULADOS

\footnotetext{
${ }^{1}$ Figura fornecida por SOARES e GENNARI, em São Paulo, em 2012.
} 
Nos anos posteriores, se deu o desenvolvimento e a padronização de métodos de diagnóstico, os quais viabilizaram a realização de estudos epidemiológicos (PARE; HIETALA; THURMOND, 1995; BJÖRKMAN; UGGLA, 1999).

Embora a ocorrência seja relativamente frequente nas diferentes espécies animais, a patogenicidade do $N$. caninum varia entre as espécies de hospedeiros. Dentre os animais domésticos, os bovinos se destacam por sua maior suscetibilidade e apresentam perdas na esfera reprodutiva como abortamentos, natimortalidade ou nascimento de bezerros aparentemente sadios, porém infectados. A infecção também pode ser transmitida da vaca para o bezerro pela via transplacentária e pode ocorrer ao longo de sucessivas gestações disseminando a infecção no rebanho (DUBEY, 1999).

Desde sua descrição, $N$. caninum vem sendo implicado como um dos principais causadores de aborto em bovinos em várias regiões do mundo. O impacto econômico da infecção por esse parasito está relacionado tanto ao valor dos fetos abortados, quanto aos custos indiretos tais como: auxílio profissional, redução da vida produtiva da vaca, alteração no tempo de lactação, possíveis quedas na produção de leite e custos com diagnóstico (THURMOND; HIETALA; BLANCHARD, 1997).

Neospora caninum já foi identificado em tecidos de cães, os quais são hospedeiros definitivos e intermediários (DUBEY et al., 1988b), de ovelhas (DUBEY et al., 1990; PENA et al., 2007), de bovinos (ANDERSON et al., 1991; DIJKSTRA et al., 2002), de cabras (BARR et al., 1993), de cervídeos (DUBEY et al., 1996; VIANNA et al., 2005), de equinos (DUBEY et al., 1999), de suínos (AZEVEDO et al., 2010) e de búfalos (RODRIGUES et al., 2004). Em tecidos de galinhas $N$. caninum já foi detectado por métodos moleculares (COSTA et al., 2008).

Dentre os animais domésticos, anticorpos anti- $N$. caninum já foram verificados em gatos (DUBEY et al., 2002; FERROGLIO et al., 2005; BRESCIANI et al., 2007), suínos (HELMICK et al., 2002; DAMRIYASA et al., 2004), ovinos (HELMICK et al., 
2002; HÄSSIG et al., 2003; FIGLIUOLO et al., 2004; VOGEL et al., 2006; ROMANELLI et al., 2007; ROSSI et al., 2011), caprinos (DUBEY et al., 1996; NAGULESWARAN et al., 2004; FIGLIUOLO et al., 2004; CZOPOWICS et al., 2011), búfalos (FUJIl et al., 2001; GENNARI et al., 2005), bovinos (MARQUES et al., 2011; XIA et al., 2011; EIRAS et al., 2011) e em equinos (DUBEY et al., 1999; HOANE et al., 2006; LOCATELLI-DITRICH et al., 2006; VILLALOBOS et al., 2006; MORAVEJI et al., 2011).

Em animais silvestres, anticorpos anti- $N$. caninum já foram encontrados em alpacas, Ihamas, camelos (HILALI et al., 1998; SADREBAZZAZ et al., 2006), gambás (YAl et al., 2003), capivaras (YAl et al., 2008), raposas (BUXTON et al., 1997) e coiotes (STIEVE et al., 2010) entre outros. Num estudo realizado no Brasil com cervídeos, verificou-se ocorrência de anticorpos significativamente superior nos cervídeos que viviam em locais próximos aos humanos e seus animais domésticos, quando comparados a cervídeos com menor contato com os animais domésticos (TIEMANN et al., 2005). Tal fato reforça a importância do cão na epidemiologia do agente no ambiente silvestre.

Os coiotes (Canis latrans) também foram confirmados como hospedeiros definitivos do coccídio, eliminando oocistos em suas fezes (GONDIM et al., 2004). Recentemente, na Austrália, King et al. (2010) verificaram que o cão australiano dingo (Canis lupus dingo) é hospedeiro definitivo do $N$. caninum e Dubey et al. (2011), nos Estados Unidos, observaram que lobos cinzentos (Canis lupus) eliminaram oocistos desse coccídio. É desconhecido se outros canídeos ou até mesmo outras espécies animais possam atuar como hospedeiros definitivos de $N$. caninum.

Isolados de N. caninum em cães foram obtidos nos Estados Unidos (DUBEY et al., 1988b; CUDDON et al., 1992; MARSH et al., 1998), Reino Unido (BARBER et al., 1995), Alemanha (PETERS; WAGNER; SCHARES, 2000), Brasil (GONDIM et al., 2001), Argentina (BASSO et al., 2001) e Portugal (BASSO et al., 2009). 
O primeiro estudo para detectar a presença de anticorpos anti- $N$. caninum em equinos foi realizado por Dubey et al. (1999). Os autores examinaram 296 amostras de soro de equinos destinados ao abate através do NAT (Neospora Agglutination Test), com ponto de corte estabelecido na diluição 1:40. A frequência da ocorrência de anticorpos foi de 23,3\% (69 positivos) com títulos de 40 (19), 80 (19), 100 (3), $400,(4)$ e 800 (17).

No Brasil, foram encontrados anticorpos anti-Neospora spp. em equinos de diversos estados como: Minas Gerais, Santa Catarina, Rio Grande do Sul, Mato Grosso do Sul e Goiás pelo ELISA (HOANE et al., 2006), em São Paulo (VILLALOBOS et al., 2006) e Paraná (LOCATELLI-DITTRICH et al., 2006), pela Reação de Imunofluorescência Indireta (RIFI) com ponto de corte de 50 e com valores que variaram de $1,6 \%$ a $47 \%$ de positividade.

Nos Estados Unidos, Marsh et al. $(1996,1998)$ identificaram uma nova espécie de Neospora em um cavalo adulto que apresentava severa incoordenação motora, tendo o parasita sido isolado de cérebro e medula espinhal. Essa nova espécie foi denominada Neospora hughesi por possuir diferenças estruturais e moleculares em relação a $N$. caninum.

Existem ainda incertezas com relação às consequências da infecção por estes parasitos em equinos. As principais diferenças entre eles é que os bradizoítos de $N$. hughesi parecem ser menores, os oocistos e os hospedeiros definitivos do $N$. hughesi ainda não foram identificados, os antígenos de $N$. hughesi possuem diferentes proteínas das observadas em $N$. caninum (as proteínas de grânulos densos de $N$. hughesi são diferentes das proteínas correspondentes de $N$. caninum) e os parasitos tem um comportamento biologicamente diferente quando inoculados em roedores, isto é, os gerbilos não são suscetíveis a $N$. hughesi, mas são suscetíveis a N. caninum (WALSH et al., 2000; DUBEY et al., 2002).

Dubey e Portfield (1986) relataram o primeiro caso de neosporose em feto equino abortado em 1985. Lindsay et al. (1996) observaram uma égua com cegueira 
parcial e encontraram um cisto tecidual de Neospora spp. no sistema nervoso central (SNC) desse animal.

Em equinos a neosporose pode causar aborto, doenças neonatais, viscerais, e neurológicas. A neosporose foi diagnosticada em cavalos adultos com sinais clínicos semelhantes aos da mieloencefalite protozoária equina (EPM), causada pelo protozoário Sarcocystis neurona (MARSH et al., 1996).

Neosporose visceral foi descrita em fêmea da espécie equina da raça Appaloosa com histórico de perda de peso e anemia (GRAY et al., 1996). Foram encontrados taquizoítos em linfonodos mesentéricos e intestino delgado do animal, os quais foram identificados pela imuno-histoquímica.

Daft et al. (1997) diagnosticaram neosporose em uma égua de 19 anos que apresentava paralisia do membro posterior e comportamento anormal. O protozoário foi observado no SNC, medula espinhal e nervos periféricos. $O$ animal apresentou sinais da Doença de Cushing, o que deve ter contribuído para a imunossupressão e reativação de infecção latente por Neospora spp.

Doença neurológica causada por $N$. hughesi foi diagnosticada em cavalos adultos nos Estados Unidos. Houve um caso de infecção por Neospora em equino da raça quarto de milha com 13 anos de idade, procedente do Alabama, EUA. O animal apresentou ataxia e fraqueza no membro posterior durante cinco meses. $\mathrm{Na}$ necropsia nenhuma lesão macroscópica foi evidenciada (CHEADLE et al., 1999).

O primeiro caso de EPM causado pelo Neospora hughesi no Canadá foi relatado por Woebeser et al. (2009). O protozoário foi identificado como N. hughesi, tendo sido encontrado em lesões infamatórias de SNC de um equino adulto com 10 anos de idade. $\mathrm{O}$ animal apresentou sinais neurológicos como ataxia, dificuldade em erguer-se e foi sacrificado. Nos cortes histológicos de vários órgãos, corados pela hematoxilina-eosina, lesões significantes foram encontradas na porção cervical e SNC, tais como agregado linfocitário multifocal ou circunferencial à massa encefálica. Para confirmação do diagnóstico foi realizada a imuno-histoquímica, sendo positiva para Neospora e logo após a PCR para diagnóstico de espécie. 
Outro relato de caso de EPM causada por $N$. hughesi foi feito na Califórnia. Em uma mula com enfermidade motora, anormalidades oculares e andar cambaleante observou-se anisocoria, estrabismo, ptose palpebral, déficit do reflexo pupilar, dentre outros. Anormalidades neurológicas incluíam paralisia do nervo facial e atrofia muscular neurogênica. Para confirmação de mieloencefalite pelo $N$. hughesi foram realizados apenas testes sorológicos para a presença de Sarcocystis neurona com resultado negativo e a reação de imunofluorescência indireta (RIFI) para $N$. hughesi com título de 40, sendo estes considerados positivos (FINNO et al., 2010).

Cheadle et al. (1999) utilizaram a RIFI, com ponto de corte de 50, para determinar a frequência da ocorrência de anticorpos específicos para $N$. caninum nos soros de 536 equinos do Alabama, Estados Unidos, sem sintomatologia clínica e submetidos ao diagnóstico de Anemia Infecciosa Equina. Anticorpos IgG antiNeospora spp. estavam presentes em $62(11,5 \%)$ animais, com títulos de 1:50 em 35 animais (6,5\%), 1:100 em 19 animais (3,5\%), 1:200 em 7 animais (1,3\%) e 1:600 em um animal $(0,2 \%)$.

Com o objetivo de verificar a existência de associação entre a presença de anticorpos séricos anti-Neospora spp. e histórico recente de falhas reprodutivas em animais da espécie equina, Villalobos et al. (2006) realizaram um estudo com 1106 amostras de soros de equinos. As amostras foram divididas em dois grupos: animais com falhas reprodutivas (500 equinos) e grupo controle sem falhas reprodutivas (606 equinos). Pela RIFI ( $\geq 50$ ) anticorpos anti-Neospora spp. foram encontrados em 114 $(10,3 \%)$ animais sendo $15,4 \%$ (77/500) para os com falhas reprodutivas e de $6,1 \%$ (37/606) para os controles. Associação entre positividade para Neospora spp. e a presença de distúrbios reprodutivos foi observada.

Villalobos et al. (2012) realizaram um estudo de prevalência de anticorpos anti-Neospora sp. em 97 cavalos de carroceiros aparentemente saudáveis de Curitiba (25) e São José dos Pinhais (72), Paraná, utilizando a RIFI e encontraram um (4\%) e $13(18 \%)$ animais, respectivamente, positivos para esse coccídio. 


\subsection{Toxoplasma gondii}

As primeiras descrições de $T$. gondii ocorreram quase simultaneamente em diferentes partes do mundo. No Brasil, Splendore (1908) descreveu o parasita em coelhos e, na África, Nicolle e Manceaux (1908) descreveram taquizoítos do parasita em tecidos de um roedor africano, Ctenodactylus gundi. Em 1909, Nicolle e Manceaux introduziram o gênero Toxoplasma. O nome Toxoplasma (toxo = arco; plasma $=$ forma, grego) refere-se a sua forma em lua crescente. Mais de 60 anos depois, em 1970, o conhecimento sobre o ciclo biológico de $T$. gondii foi completado através da descoberta dos estágios sexuais do parasito no intestino delgado de gatos (DUBEY; MILLER; FRENKEL, 1970a, b).

O ciclo biológico de $T$. gondii é heteroxeno facultativo. A fase assexuada de desenvolvimento ocorre em vários tecidos dos hospedeiros intermediários (mamíferos e aves), resultando na formação de cistos, e a fase sexuada de desenvolvimento ocorre no intestino delgado dos hospedeiros definitivos (gatos domésticos e outros membros da família Felidae), resultando na formação dos oocistos (DUBEY; BEATTIE, 1988; LINDSAY; BLAGBURN; DUBEY, 1997). Há três estágios infectantes que são os taquizoítos livres ou em pseudocistos em diversos órgãos, os bradizoítos nos cistos teciduais e os esporozoítos nos oocistos esporulados. Os três estágios são infectantes para hospedeiros intermediários e definitivos (DUBEY; BEATTIE, 1988).

Nos hospedeiros intermediários, após a infecção com qualquer dos estágios infectantes, há a multiplicação rápida dos taquizoítos por endodiogenia em diferentes tipos de células, culminando na formação dos cistos teciduais. Os cistos contêm bradizoítos, que são estágios que se dividem lentamente, também por endodiogenia, e se localizam predominantemente no cérebro e musculatura cardíaca e esquelética, persistindo por um longo período, provavelmente por toda a 
vida do hospedeiro (DUBEY; FRENKEL, 1972; DUBEY; FRENKEL, 1976; DUBEY; BEATTIE, 1988).

Os felinos são considerados as espécies-chave na transmissão de $T$. gondii para o Homem e outras espécies animais por serem os únicos hospedeiros a excretarem os oocistos nas fezes (DUBEY; BEATTIE, 1988). Um único gato pode eliminar até 10 milhões de oocistos, que se tornam infectantes após esporulação no ambiente (DUBEY; MILLER; FRENKEL, 1970a; FRENKEL; DUBEY; MILLER, 1970).

Todos os gatos domésticos são suscetíveis à infecção, independentemente de sexo, idade ou raça (DUBEY; HOOVER; WALLS, 1977) e aqueles com menos de um ano de idade produzem o maior número de oocistos; animais adultos não infectados também eliminam oocistos ao ingerirem cistos, mas a excreção é menor e por um período mais curto (DUBEY; HOOVER; WALLS, 1977; DUBEY; BEATTIE, 1988; LINDSAY; BLAGBURN; DUBEY, 1997).

Os gatos adquirem uma forte imunidade intestinal após a primo-infecção, raramente re-excretando oocistos. Dubey (1995) observou uma nova eliminação em $55 \%$ de gatos desafiados seis anos após a infecção primária. Alguns gatos podem eliminar novamente oocistos, mesmo sem reinfecção, quando imunodeprimidos ou infectados com Isospora spp (CHESSUM, 1972; DUBEY; FRENKEL, 1974; DUBEY, 1976).

A figura 2 ilustra o ciclo biológico de $T$. gondii. 
Figura 2 - Ciclo de Biológico de Toxoplasma gondii.

Fonte: (SOARES; GENNARI, 2012)2.

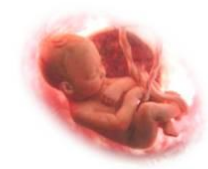

FETO INFECTADO
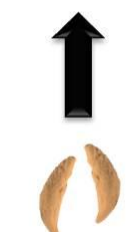

TAQUIZOITOS
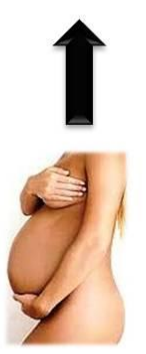

HOSPEDEIRO INTERMEDIÁRIO

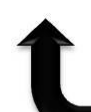

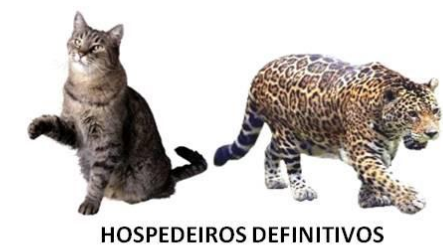
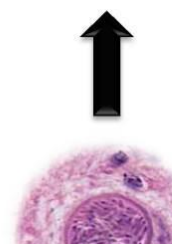

CISTOS TECIDUAIS
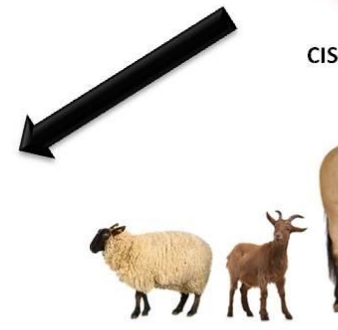

HOSPEDEIROS INTERMEDIÁRIOS

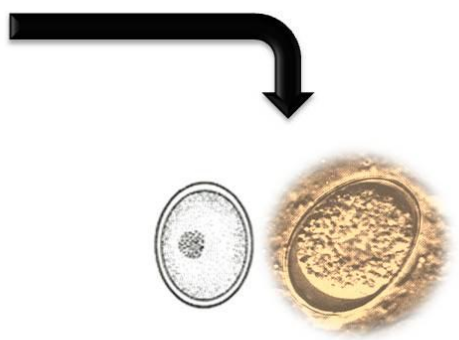

OOCISTOS NÃO ESPORULADOS NAS FEZES

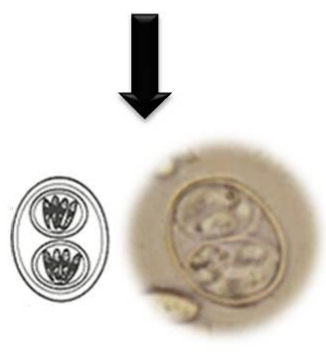

OOCISTOS ESPORULADOS

Os equinos parecem ser uma das espécies mais resistentes no desenvolvimento clínico da toxoplasmose (AL-KHALID; DUBEY, 1979), entretanto, sinais clínicos caracterizados por hiper irritabilidade, incoordenação motora, distúrbios oculares e abortamento já foram relatados (DUBEY; PORTFIELD, 1986; TURNER; SAVVA, 1991),

Dubey, Kerber e Granstrom (1999) afirmaram que não há evidências de que a doença clínica ocorra em equinos, enfatizando que os cistos teciduais do parasito podem persistir no tecido por vários meses.

A prevalência do $T$. gondii em equinos é muito baixa e Dubey et al. (1999) consideram que o risco de contrair infecção através do consumo da carne desses animais seria bastante baixo e esta espécie não teria uma importância

\footnotetext{
${ }^{2}$ Figura fornecida por Soares e Gennari, em São Paulo, em 2012.
} 
epidemiológica significativa. No entanto, a carne de equinos pode veicular cistos de T. gondii, representando assim, um problema de saúde pública. Além disso, constituem uma fonte de infecção para animais de zoológico que são alimentados com esse tipo de carne, em especial os felídeos silvestres que são hospedeiros definitivos do agente, podendo eliminá-lo no meio ambiente por meio das fezes (MENDONÇA et al., 2001).

No Brasil, Macruz et al. (1975) relataram o surgimento, em equinos Puro Sangue Inglês do Estado de São Paulo, de casos clínicos caracterizados por incoordenação motora, andar em círculo, abortamento e irritabilidade excessiva sugerindo tratar-se de toxoplasmose, após a eliminação de outras causas. Foram realizadas provas sorológicas nos soros destes animais revelando $100 \%$ de positividade ao teste de Sabin-Feldman. A conclusão dos autores foi de que estes animais estavam acometidos de toxoplasmose recém-introduzida neste rebanho. Vale lembrar que nesse período, outro coccídio responsável por quadro semelhante, Sarcocystis neurona, ainda não tinha sido associado a essa doença.

O quadro 1 relaciona os estudos de pesquisa de anticorpos contra $T$. gondii em equinos no Brasil, indicando o teste sorológico e o ponto de corte. 
Quadro 1 - Relação dos estudos de pesquisa de anticorpos anti-Toxoplasma gondii realizados no Brasil com equídeos

\begin{tabular}{|c|c|c|c|c|c|}
\hline Referência & Estado (Município) & Amostras Analisadas & $\%$ de Positivas & Teste & Ponto de corte \\
\hline \multicolumn{6}{|l|}{ CAVALOS } \\
\hline Ishizuka; Miguel; Brogliato (1975) & São Paulo (São Paulo) & 327 & 70 & RIFI & 16 \\
\hline Silva et al. (1981) & Rio Grande do Sul (Porto Alegre) & 100 & 8 & IHA & 16 \\
\hline Laranjeira; Ishizuka; Hyakutake (1985) & Mato Grosso do Sul & 750 & 32 & RIFI & 16 \\
\hline Braccini et al. (1992) & Rio Grande do Sul (Porto Alegre) & 98 & 2 & IHA & 63 \\
\hline Gazêta et al. (1997) & Rio de Janeiro (12 cidades) & 430 & 4,4 & RIFI & 64 \\
\hline Vidotto et al. (1997) & Paraná (Apucarana) & 561 & 31,5 & RIFI & 16 \\
\hline Garcia et al. (1999) & Paraná (Jaguapitã) & 173 & 12,1 & RIFI & 16 \\
\hline Mendonça et al. (2001) & Bahia (Jacobina e Jequié) & 124 & 1,61 & RIFI & 64 \\
\hline Naves; Ferreira; Costa (2005) & Minas Gerais (Uberlândia) & 117 & 12,8 & RIFI & Nc \\
\hline Villalobos et al. (2005) & São Paulo (Vale do Ribeira) & 170 & 47 & RIFI & 64 \\
\hline \multicolumn{6}{|l|}{ JUMENTOS } \\
\hline Mendonça et al. (2001) & Bahia (Jacobina e Jequié) & 197 & 1,52 & RIFI & 64 \\
\hline Oliveira et al. (2012) & Pernambuco, Rio Grande do Norte, Paraíba e Sergipe & 88 & 43,2 & RIFI & 64 \\
\hline \multicolumn{6}{|l|}{ MULAS } \\
\hline Mendonça et al. (2001) & Bahia (Jacobina e Jequié) & 22 & 0 & RIFI & 64 \\
\hline Oliveira et al. (2012) $)^{3}$ & Pernambuco, Rio Grande do Norte, Paraíba e Sergipe & 395 & 23,8 & RIFI & 64 \\
\hline
\end{tabular}

\footnotetext{
${ }^{3}$ OLIVEIRA, E.; ALBUQUERQUE, P. P. F; NETO, O. L. S.; FARIA, E. B.; JUNIOR, J. W. P.; MOTA, R. A. Occurrence of Antibodies to Toxoplasma gondii in Mules and Donkeys in the Northeast of Brazil. Journal of Parasitology, 2012. No prelo
} 
Fora do Brasil estudos de ocorrência de anticorpos anti- $T$. gondii em equinos foram realizados na Tunísia com ocorrência de 17,7\% de positivos (BOUGHATTAS et al., 2011), Costa Rica com 34\% (DANGOUDOUBIYAM et al., 2011), México com 6,1\% (ALVARADO-ESQUIVEL et al., 2012) e Espanha, sendo 10,8\% em cavalos, $15 \%$ em mulas e $25,6 \%$ em jumentos (GARCIA-BOCANEGRA et al., 2012).

Devido ao uso de amostragens distintas, técnicas e pontos de corte diversos, comparações entre valores de ocorrência devem ser feitas com cuidado.

\subsection{Animais do Estudo}

No Brasil, segundo dados do IBGE de 2010 existiam 1.277.419 mulas, 1.001.587 jumentos e 5.514.253 cavalos.

\subsubsection{JUMENTOS}

O jumento (Equus asinus) é um mamífero pertencente à família dos Equídeos, podendo ser chamado de jégue ou asno.

Em alguns países se utilizam jumentos para os mesmos serviços que o cavalo e o muar, como montaria, carga e tração, de acordo com seu tipo e as necessidades. No Brasil é mais comum utilizá-los como cargueiros e mais raramente como montaria, principalmente no Nordeste onde são mais numerosos. Sua maior importância está na sua capacidade de hibridar-se com a égua, produzindo o muar. 
A carne de jumento é considerada uma das melhores, superando a do cavalo. Nos últimos anos, no Nordeste, grande quantidade de jegues tem sido abatidos para a exportação da carne.

O uso do jumento reprodutor como montaria não é favorável devido a hábitos de empacar, passarinhar e morder, que podem ser hábitos hereditários ou devido a um mau adestramento (TORRES; JARDIM, 1985).

\subsubsection{CAVAlos}

Os cavalos (Equus caballus) podem superar os muares em algumas características tais como: podem se reproduzir; são mais pesados e superiores nas provas de tração; são mais rápidos e mais indicados para trabalhos gerais, convivem melhor com outros animais, tanto no trabalho quanto na cocheira.

No Brasil, a produção de carne de equinos, afastados do trabalho e da reprodução, tem aumentado, tendo por destino principal a exportação (TORRES; JARDIM, 1985).

A exportação de cavalos vivos mostrou uma expansão significativa, alcançando 524\% entre 1997 e 2009, passando de US\$702,8 mil para US\$4,4 milhões. O Brasil é o oitavo maior exportador de carne equina. Bélgica, Holanda, Itália, Japão e França são os principais importadores da carne de cavalo brasileira, também consumida nos Estados Unidos (www.agricultura.gov.br, 2010). 


\subsubsection{MULAS}

As mulas são o cruzamento de jumento com égua e são um grande auxiliar do lavrador brasileiro, na tração de máquinas agrícolas e nos transportes, tanto dentro da propriedade, como fora dela.

Os muares no Brasil são mais usados na tração de carroças, charretes, máquinas agrícolas leves (arados de aiveca, cultivadores, sulcadores, semeadeiras adubadeiras), no transporte de carga sobre o dorso, nas regiões montanhosas e acidentadas, na montaria, podendo fazer etapas de 30 a $40 \mathrm{~km} / \mathrm{dia}$, sem esgotar-se.

A densidade do casco, com muralha dura e sola arqueada, habilita-se a suportar bem as batidas e choques contra a pavimentação das ruas e os terrenos pedregosos, o que o torna um importante animal em algumas localidades (TORRES; JARDIM, 1985). 


\section{OBJETIVOS}

Este estudo teve por objetivos determinar a soroprevalência de anticorpos contra Neospora spp. e Toxoplasma gondii em equídeos do Brasil e isolamento e caracterização genética desses coccídios em amostras teciduais de equídeos soropositivos 


\section{MATERIAL E MÉTODOS}

O procedimento experimental foi realizado nos laboratórios do Setor de Doenças Parasitárias do Departamento de Medicina Veterinária Preventiva e Saúde Animal (VPS) da Faculdade de Medicina Veterinária e Zootecnia (FMVZ) da Universidade de São Paulo (USP) com aprovação da Comissão de Ética da FMVZUSP $n^{0}$ 2257/2011.

\subsection{Animais Amostrados}

Amostras de sangue foram coletadas utilizando-se seringa, agulha e frascos sem anticoagulante. Foram amostrados equídeos de propriedades rurais de cinco estados da região Nordeste do Brasil, totalizando 392 animais. Também foram amostrados 61 equinos de um frigorífico do município de Araguari, Minas Gerais, sudeste brasileiro. Nesse frigorífico a real procedência dos animais não é conhecida.

As localidades de origem das amostras estão ilustradas na figura 3.

O sangue foi mantido a temperatura ambiente por 6 horas e o soro obtido foi centrifugado a $12000 \mathrm{rpm}$ durante 5 minutos. As amostras foram aliquotadas e mantidas a $-4^{\circ} \mathrm{C}$ até as análises laboratoriais.

O quadro 2 ilustra a procedência e quantidade de amostras obtidas por espécie animal estudada. 
Figura 3- Mapa do Brasil com a localização dos estados e municípios de procedência das amostras e a quantidade amostrada

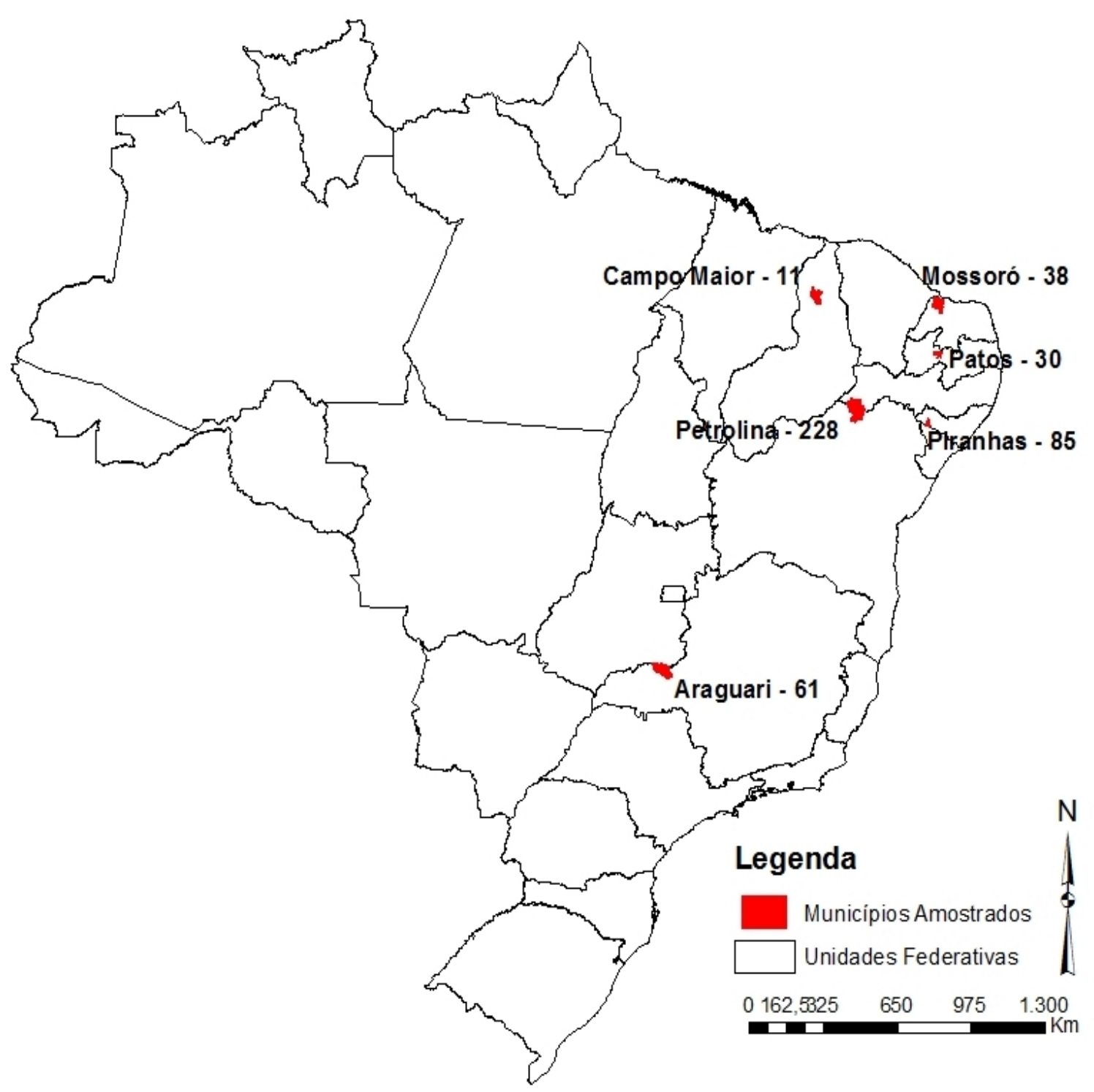


Quadro 2- Número de amostras de soros coletadas de equídeos, por município e estado

\begin{tabular}{llcccc}
\hline Município & \multicolumn{1}{c}{ Estado } & \multicolumn{4}{c}{ Número de Amostras } \\
\cline { 3 - 6 } & & Equinos & Jumentos & Mulas & Total \\
\hline Araguari & Minas Gerais & 61 & 0 & 0 & 61 \\
Campo Maior & Piauí & 0 & 11 & 0 & 11 \\
Mossoró & Rio Grande do Norte & 0 & 38 & 0 & 38 \\
Patos & Paraíba & 0 & 30 & 0 & 30 \\
Petrolina & Pernambuco & 57 & 140 & 31 & 228 \\
Piranhas & Alagoas & 0 & 85 & 0 & 85 \\
\hline TOTAL & & 118 & 304 & 31 & 453 \\
\hline
\end{tabular}

*Animais obtidos do Abatedouro do Município de Araguari (MG), procedência desconhecida.

\subsection{Análise Sorológica}

\subsubsection{N. CANINUM}

Os soros dos equídeos foram analisados utilizando a Reação de Imunofluorescência Indireta (RIFI), para anticorpos anti-N. caninum com ponto de corte de 50 conforme descrito por Dubey et al. (1988b). Os soros foram diluídos a 1:50 em tampão fostato $\mathrm{pH} 7,2\left(0,0084 \mathrm{M} \mathrm{Na} \mathrm{HPO}_{4}, 0,0018 \mathrm{M} \mathrm{NaH} \mathrm{PO}_{4}\right.$ e $0,147 \mathrm{M}$ 
$\mathrm{NaCl}$ ) acrescentado de soro albumina bovina 1\%, sendo em seguida distribuídos 20 $\mu \mathrm{L}$ por orifício em lâminas contendo o antígeno específico fixado.

Após 30 minutos de incubação em estufa a $37^{\circ} \mathrm{C}$, as lâminas foram lavadas com solução tampão carbonatada pH 9,0 $\left(0,108 \mathrm{M} \mathrm{Na}_{2} \mathrm{CO}_{3}, 0,4 \mathrm{M} \mathrm{NaHCO}{ }_{3}\right.$ e $0,145 \mathrm{M}$ $\mathrm{NaCl})$ por três vezes e, em seguida, incubadas com conjugado IgG de coelho antilgG equino (KPL- EUA) marcado com isotiocianato de fluoresceína. As lâminas foram novamente incubadas por 30 minutos a $37^{\circ} \mathrm{C}$ e lavadas como descrito anteriormente. Após a secagem à temperatura ambiente, foi realizada a montagem com lamínula utilizando glicerina tamponada pH 8,0.

A leitura das lâminas foi realizada em microscópio epifluorescente (OLYMPUS BX-FLA, Japão) e foram considerados positivos os soros capazes de determinar fluorescência em todo contorno do antígeno. As amostras positivas foram diluídas na razão dois, para obtenção do título final. Em cada série foram incluídos soros testemunhas de títulos positivo e negativo previamente conhecidos. Os soros também foram diluídos a 1:25, mas a fluorescência ocorreu apenas em região apical, sendo considerados como inespecíficos.

\subsubsection{T. GONDII}

Os soros dos equídeos foram analisados para $T$. gondii pela RIFI conforme descrito por Camargo (1964). Os soros dos animais foram diluídos a 1:64 (ISHIZUKA; MIGUEL; BROGLIATO, 1975) em tampão fostato pH 7,2 acrescentado de soro albumina bovina $1 \%$, sendo em seguida distribuídos $20 \mu \mathrm{L}$ por orifício em lâminas contendo o antígeno específico fixado. 
Após 30 minutos de incubação em estufa a $37^{\circ} \mathrm{C}$, as lâminas foram lavadas por três vezes e, em seguida, incubadas com conjugado IgG de coelho anti-lgG equino (KPL- EUA) marcado com isotiocianato de fluoresceína. As lâminas foram novamente incubadas por 30 minutos a $37^{\circ} \mathrm{C}$ e lavadas como descrito anteriormente. Após a secagem à temperatura ambiente, foi realizada a montagem com lamínula utilizando glicerina tamponada $\mathrm{pH}$ 8,0. A leitura foi realizada em microscópio epifluorescente (OLYMPUS BX-FLA, Japão).

Foram considerados positivos os soros capazes de determinar fluorescência em todo contorno do antígeno. As amostras positivas foram diluídas na razão dois, para obtenção do título final. Em cada série foram incluídos soros testemunhas de títulos positivo e negativo previamente conhecidos.

\subsection{Isolamento do T. gondii}

\subsubsection{BIOENSAIO EM CAMUNDONGOS}

De alguns dos equídeos positivos à presença de anticorpos anti- $T$. gondii pela RIFI foi possível a obtenção de tecidos e realizou-se o bioensaio em camundongos. Foram utilizados camundongos da linhagem Swiss, fêmeas, com aproximadamente dois meses de idade, numa tentativa de isolar-se $T$. gondii desses equídeos.

Cada tecido foi homogeneizado individualmente, digerido em pepsina ácida, neutralizado e lavado. Em seguida, o homogenado foi inoculado por via subcutânea nos camundongos conforme descrito por Dubey (1998). 
Um fragmento do cérebro dos camundongos que vieram a óbito foi coletado, colocado em lâminas para pesquisa de cistos de $T$. gondii. Um fragmento do pulmão foi colocado em solução fisiológica e analisado para a presença de taquizoítos de $T$. gondii. Os camundongos sobreviventes foram sangrados 60 dias pós-inoculação (P.I.) e anticorpos anti-T. gondii foram pesquisados usando a diluição de 1:16 pela RIFI. Os camundongos que não vieram a óbito foram eutanasiados oito semanas P.I. e os cérebros examinados para a presença de cistos como descrito por Dubey e Beattie (1988). Os camundongos foram considerados infectados com T. gondii quando taquizoítos ou cistos foram encontrados nos tecidos.

Os tecidos utilizados para o bioensaio em camundongos nem sempre foram os mesmos, pois dependiam das facilidades encontradas durante as necropsias. $O$ quadro 3 apresenta a relação de tecidos examinados por animal amostrado e o número de camundongos inoculados durante o bioensaio.

Devido à dificuldade de obtenção de tecidos de equídeos, 51 equinos procedentes do frigorífico de Araguari, MG, mesmo sendo negativos na RIFI tiveram seus órgãos examinados pelo bioensaio. Nesses animais, utilizou-se um pool de tecidos constituído por língua, cérebro e coração. Cada pool era formado por cinco equinos e quatro camundongos foram inoculados por pool de tecidos, sendo realizados um total de 10 pools.

Foram feitos 29 bioensaios ao todo, sendo: 19 de animais soropositivos para T. gondii e 10 bioensaios com pools de animais soronegativos. Dos 19 bioensaios de equídeos soropositivos, em nove deles 20 camundongos foram inoculados com: cérebro (cinco camundongos), coração (cinco camundongos), língua (cinco camundongos) e diafragma (cinco camundongos) e nos outros 10 bioensaios de pools de animais utilizou-se 10 camundongos, com material do cérebro (quatro camundongos), língua (três camundongos) e coração (três camundongos) dos equídeos. 
De nenhum dos animais soropositivos para Neospora spp. foi possível a obtenção de tecidos, não tendo sido possível a tentativa de isolamento desse coccídio por bioensaio em gerbilos. 
Quadro 3- Distribuição do número de camundongos por tecidos de equídeos e identificação das espécies analisadas

\begin{tabular}{|c|c|c|c|}
\hline Espécie & Município (Estado) & Identificação & $\begin{array}{l}\text { Número de camundongos } \\
\text { inoculados }\end{array}$ \\
\hline \multirow[t]{9}{*}{ Jumentos } & Mossoró (RN) & Mo 6 & $20^{*}$ \\
\hline & Patos (PB) & Pa 31 & $20^{*}$ \\
\hline & Patos (PB) & $\mathrm{Pa} 37$ & $20^{*}$ \\
\hline & Patos (PB) & $\mathrm{Pa} 41$ & $20^{*}$ \\
\hline & Piranhas (AL) & $\mathrm{Pi} 294$ & $20^{*}$ \\
\hline & Piranhas (AL) & Pi 295 & $20^{*}$ \\
\hline & Piranhas (AL) & Pi 296 & $20^{*}$ \\
\hline & Piranhas (AL) & Pi 297 & $20^{*}$ \\
\hline & Piranhas (AL) & $\mathrm{Pi} 298$ & $20^{*}$ \\
\hline \multirow[t]{20}{*}{ Cavalos } & Araguari (MG) & Ar 379 & $10^{\square}$ \\
\hline & Araguari (MG) & Ar 380 & $10^{\square}$ \\
\hline & Araguari (MG) & Ar 381 & $10^{\square}$ \\
\hline & Araguari (MG) & Ar 382 & $10^{\square}$ \\
\hline & Araguari (MG) & Ar 383 & $10^{\square}$ \\
\hline & Araguari (MG) & Ar 384 & $10^{\square}$ \\
\hline & Araguari (MG) & Ar 385 & $10^{\square}$ \\
\hline & Araguari (MG) & $\operatorname{Ar} 386$ & $10^{\square}$ \\
\hline & Araguari (MG) & Ar 387 & $10^{\square}$ \\
\hline & Araguari (MG) & Ar 388 & $10^{\square}$ \\
\hline & Araguari (MG) & Pool 1 & $4^{\ominus}$ \\
\hline & Araguari (MG) & Pool 2 & 4 \\
\hline & Araguari (MG) & Pool 3 & 4 \\
\hline & Araguari (MG) & Pool 4 & 4 \\
\hline & Araguari (MG) & Pool 5 & 4 \\
\hline & Araguari (MG) & Pool 6 & 4 \\
\hline & Araguari (MG) & Pool 7 & $4^{\diamond}$ \\
\hline & Araguari (MG) & Pool 8 & $4^{\diamond}$ \\
\hline & Araguari (MG) & Pool 9 & $4^{0}$ \\
\hline & Araguari (MG) & Pool 10 & $4^{0}$ \\
\hline
\end{tabular}

* Órgãos analisados ( $\mathrm{n}^{\circ}$ de camundongos): cérebro (5), diafragma (5), língua (5), coração (5)

- Órgãos analisados ( $\mathrm{n}^{\circ}$ de camundongos): cérebro (4), língua (3), coração (3)

- Pools de 5 equídeos- órgãos analisados ( $n^{\circ}$ de camundongos): cérebro/língua/coração (4) 


\subsection{Identificação Molecular dos Protozoários}

Para a identificação molecular dos protozoários foi realizada a extração de DNA utilizando o fenol-clorofórmio, PCR, nested- PCR. As amostras foram processadas no laboratório de Encefalites do Instituto Biológico da Secretaria do Município de São Paulo.

\subsubsection{EXTRAÇÃO DE DNA}

O DNA foi extraído de tecidos dos equídeos submetidos ao bioensaio (amostras primárias) e dos isolados obtidos no modelo camundongo, conforme os seguintes procedimentos:

As etapas de digestão, purificação e precipitação do DNA foram feitas conforme sugerido por Ausubel et al. (1999). Brevemente, uma alíquota de 500 $\mu \mathrm{L}$ dos tecidos foram digeridos com proteinase $\mathrm{K}(20 \mathrm{mg} / \mu \mathrm{L})$, o DNA foi purificado pelo método de fenol-clorofórmio ( $\mathrm{v} / \mathrm{v})$, precipitado com etanol $70 \%$ e finalmente ressuspendido em $\mathrm{TE} \mathrm{pH} 8,0$ e estocado a $-20^{\circ} \mathrm{C}$ até a reação de PCR. 


\subsubsection{PCR E NESTED-PCR}

A amplificação das sequências do ITS-1 dos protozoários da família Toxoplasmatinae foi obtida em duas etapas.

A PCR foi realizada com os primers externos JS4 (SLAPETA et al., 2002) e CT2c (SOARES et al., 2011) e na nested-PCR com os primers internos JS4b e CT2b (SOARES et al., 2011). As sequências senso e antisenso destes primers estão apresentadas no quadro 4.

Quadro 4 - Sequência de primers utilizados nas reações de PCR e da nested PCR- ITS1 para identificação de protozoários da família Toxoplasmatinae

\begin{tabular}{|ll|}
\hline Primers & Sequência (5' - 3') \\
\hline JS4 & CGA AAT GGG AAG TTT TGT GAA C \\
CT2c & CTG CAA TTC ACA TTG CGT TTC GC \\
JS4b & AGT CGT AAC AAG GTT TCC GTA GG \\
CT2b & TTG CGC GAG CCA AGA CAT C \\
\hline
\end{tabular}

Na PCR, 2,5 $\mu \mathrm{L}$ de DNA foram diluídos em 22,5 $\mu \mathrm{L}$ de mix de PCR, conforme o seguinte protocolo de reação:

$>2,5 \mu \mathrm{L}$ de tampão de reação $\left(\mathrm{KCl} 8 \mathrm{mM}\right.$ : tris $-\mathrm{HCl} 10 \mathrm{mM}, \mathrm{pH} 9,0$, Invitrogen ${ }^{\circledR}$, Estados Unidos)

$>0,5 \mu \mathrm{L}$ da mistura de dNTPs $(10 \mathrm{mM})$

$>1,5 \mu \mathrm{L}$ do primer JS4 $(10 \mu \mathrm{M})$

$>1,5 \mu \mathrm{L}$ do primer CT2c $(10 \mu \mathrm{M})$

$>0,75 \mu \mathrm{L}$ de $\mathrm{MgCl}_{2}(50 \mathrm{mM}$, Invitrogen $\AA$, Estados Unidos) 
$>0,15 \mu \mathrm{L}$ de taq DNA polimerase (Platinum® Taq DNA Polymerase, Invitrogen ®), Estados Unidos) $(5 \mathrm{U} / \mu \mathrm{L})$

$>$ Água ultrapura $15,6 \mu \mathrm{L}$

Os produtos da PCR foram utilizados como template numa segunda etapa (nested- PCR) utilizando $24,5 \mu \mathrm{L}$ da mesma mistura de reação descrita e $1 \mu \mathrm{L}$ do produto da PCR, com a substituição dos primers (JS4b e CT2b).

O ciclo de reação utilizado foi o seguinte:

Desnaturação inicial $94^{\circ} \mathrm{C}$ por $3 \mathrm{~min}$

Desnaturação $94^{\circ} \mathrm{C}$ por $40 \mathrm{seg}$

Hibridização $56^{\circ} \mathrm{C}$ por $30 \mathrm{seg}$

Extensão $72^{\circ} \mathrm{C}$ por $30 \mathrm{seg}$

Este ciclo repetiu-se por 35 vezes a partir da desnaturação até a extensão na PCR e na nested- PCR, a $72^{\circ} \mathrm{C}$ por $5 \mathrm{~min}$.

Controles negativos e positivos ( $\mathrm{RH}$ - Toxoplasma gondii) foram incluídos a cada reação. Os produtos da nested PCR- ITS-1 foram analisados em gel de agarose a $2 \%$ corado com brometo de etídeo (solução a $0,5 \mu \mathrm{g} / \mathrm{mL}$ ) por 30 minutos e documentado sob transiluminação com luz ultravioleta para visualização das bandas. Foi esperado um padrão de banda de 500pb para a família Toxoplasmatinae. 


\subsection{Caracterização Genética dos Isolados de Toxoplasma gondii}

Para a caracterização genética foi realizada a PCR- RFLP do isolado do jumento de Mossoró, RN.

\subsubsection{MARCADORES}

Foram utilizados 12 marcadores moleculares que permitem distinguir, as linhagens clonais tipo I, tipo II e III. Após a amplificação do DNA, este foi submetido a enzimas de restrição, numa reação de RFLP como descrito por Su, 2006. No quadro 5 , podem ser visualizadas as informações referentes aos marcadores utilizados, localização, oligonucleotídeos iniciadores (primers), tamanho dos produtos obtidos e enzimas de restrição.

\subsubsection{PCR E NESTED-PCR}

As sequências de DNA-alvo foram primeiramente amplificadas por multiplex PCR usando primers externos para todos os marcadores, seguido de nested- PCR de forma individual, para cada um dos marcadores. 
Foi utilizada a seguinte mistura de reagentes na PCR, para uma reação em $25 \mu \mathrm{L}$ : tampão de reação ( $\mathrm{KCl} 50 \mathrm{mM}$; Tris- $\mathrm{HCl} 10 \mathrm{mM}, \mathrm{pH} 9,0), 200 \mu \mathrm{M}$ de cada nucleotídeo (dATP, dTTP, dCTP, dGTP), 0,3 $\mu \mathrm{M}$ de cada primer, $2 \mathrm{mM}$ de $\mathrm{MgCl}_{2}, 0,75$ unidades de Taq DNA polimerase e 1,5 $\mu \mathrm{L}$ de DNA extraído. Na nested-PCR foi utilizada a mesma mistura e 1,5 $\mu \mathrm{L}$ da amostra amplificada. A genotipagem dos controles positivos e das amostras de referência utilizados em todas as corridas de PCR pode ser visualizada no Quadro 6. Como controle negativo foi utilizada água ultrapura estéril.

A mistura de reação da PCR foi submetida a uma desnaturação inicial $\left(95^{\circ} \mathrm{C}\right.$ por 4 min), seguida de 25 ciclos de desnaturação $\left(94^{\circ} \mathrm{C}\right.$ por $\left.30 \mathrm{seg}\right)$, hibridização $\left(55^{\circ} \mathrm{C}\right.$ por 30 seg) e extensão $\left(72^{\circ} \mathrm{C}\right.$ por $\left.1.5 \mathrm{~min}\right)$. A mistura de reação da nested- PCR foi submetida a uma desnaturação inicial $\left(95^{\circ} \mathrm{C}\right.$ por $\left.4 \mathrm{~min}\right)$, seguida de 35 ciclos de desnaturação $\left(94^{\circ} \mathrm{C}\right.$ por $30 \mathrm{seg})$, hibridização ( $60^{\circ} \mathrm{C}$ por $\left.1 \mathrm{~min}\right)$ e extensão $72^{\circ} \mathrm{C}$ por $2 \mathrm{~min}$.

\subsubsection{PCR-RFLP}

A fim de investigar o padrão de RFLP de cada amostra, $3 \mu \mathrm{L}$ de cada produto de nested-PCR foram misturados em $17 \mu \mathrm{L}$ de reação de digestão contendo tampão NEB (1x), 0,1 mg/ml de BSA, e uma unidade de cada enzima de restrição. As amostras foram incubadas na temperatura indicada pelo fabricante como ideal para cada enzima. Após a incubação, as amostras foram submetidas à análise em gel de agarose a 2,0-3,0\%, contendo $0,3 \mu \mathrm{g}$ de brometo de etídeo, em cuba horizontal com solução tampão TBE, pH 8,0 (Tris-borato 0,045M; EDTA 0,001M), juntamente com um marcador de peso molecular com fragmentos múltiplos de 100 pares de bases, e visualizadas sob luz ultravioleta, utilizando-se um analisador de imagem (Alpha Innotech Corp, San Leandro, CA,USA). 
Quadro 5 - Informações referentes aos marcadores genéticos e às endonucleases utilizadas na PCR/RFLP

\begin{tabular}{|c|c|c|c|c|c|c|}
\hline Marcador & № cromossomo & PCR primers & $\begin{array}{l}\text { Tamanho } \\
\text { (bp) }\end{array}$ & $\begin{array}{l}\text { Enzimas de } \\
\text { Restrição }\end{array}$ & Digestão enzimática e eletroforese & Referência \\
\hline $\mathrm{c} 22-8$ & lb & $\begin{array}{l}\text { c22-8F:TCTCTCTACGTG- GACGCC c22- } \\
\text { 8R:AGGTGCTTG- GATATTCGC }\end{array}$ & 521 & $\begin{array}{l}\text { BsmAl, } \\
\text { Mboll }\end{array}$ & $\begin{array}{c}\text { NEB2, BSA, } 37^{\circ} \mathrm{C} 30 \mathrm{~min} 55^{\circ} \mathrm{C} 30 \mathrm{~min} \\
2.5 \% \mathrm{gel}\end{array}$ & $\begin{array}{l}\text { Khan et al. (2005) } \\
\text { Su et al. (2006) }\end{array}$ \\
\hline c29-2 & III & $\begin{array}{l}\text { c29-2F:AGTTCTGCA- GAGTGTCGC c29- } \\
\text { 2R:TGTCTAGGAAAGAGGCGC }\end{array}$ & 446 & HpyCH4IV, Rsal & $\mathrm{NEB} 1, \mathrm{BSA}, 37^{\circ} \mathrm{C} 60 \mathrm{~min} 2.5 \% \mathrm{gel}$ & $\begin{array}{l}\text { Khan et al. (2005) } \\
\text { Su et al. (2006) }\end{array}$ \\
\hline L358 & v & $\begin{array}{l}\text { L358-F2:AGGAGGCG- TAGCGCAAGT L358- } \\
\text { R2:CCCTCTGGCTGCAGTGCT }\end{array}$ & 418 & $\begin{array}{l}\text { Haelll, } \\
\text { NlallI }\end{array}$ & NEB4, BSA, $37^{\circ} \mathrm{C} 60 \mathrm{~min} 2.5 \% \mathrm{gel}$ & $\begin{array}{l}\text { Khan et al. (2005) } \\
\text { Su et al. (2006) }\end{array}$ \\
\hline PK1 & $\mathrm{VI}$ & $\begin{array}{l}\text { PK1-F:CGCAAAGGGAGA-CAATCAGT PK1- } \\
\text { R:TCATCGCT-GAATCTCATTGC }\end{array}$ & 903 & $\begin{array}{l}\text { Aval, } \\
\text { Rsal }\end{array}$ & NEB4, BSA, $37^{\circ} \mathrm{C} 60 \mathrm{~min} 2.5 \% \mathrm{gel}$ & $\begin{array}{l}\text { Khan et al. (2005) } \\
\text { Su et al. (2006) }\end{array}$ \\
\hline SAG1 & VIII & $\begin{array}{l}\text { SAG1-F:GTTCTAACCACGCACCCTGAG } \\
\text { SAG1-R:AAGAGTGGGAGGCTCTGTGA }\end{array}$ & 390 & $\begin{array}{l}\text { Sau961, } \\
\text { Haell }\end{array}$ & NEB4, BSA, $37^{\circ} \mathrm{C} 60 \mathrm{~min} 2.5 \% \mathrm{gel}$ & Grigg et al. (2001) \\
\hline $\begin{array}{l}53^{\prime} \\
\text { SAG2 }\end{array}$ & VIII & $\begin{array}{l}\text { SAG2-F:TCTTGTTCTCCGAAGTGACTCC } \\
\text { SAG2- R:TCAAAGCGTGCATTATCGC }\end{array}$ & 222 & Hhal & NEB4, BSA, $37^{\circ} \mathrm{C} 60 \mathrm{~min} 2.5 \%$ gel & $\begin{array}{l}\text { Khan et al. (2005) } \\
\text { Su et al. (2006) }\end{array}$ \\
\hline $\begin{array}{l}\text { alt. } \\
\text { SAG2 }\end{array}$ & VIII & $\begin{array}{l}\text { SAG2Fa:ACCCATCTGCGAA- GAAAACG } \\
\text { SAG2-Ra:ATTTC- GACCAGCGGGAGCAC }\end{array}$ & 546 & $\begin{array}{l}\text { Hinfl, } \\
\text { Taql }\end{array}$ & $\begin{array}{c}\mathrm{NEB} 3, \mathrm{BSA}, 37^{\circ} \mathrm{C} 30 \mathrm{~min}, 65^{\circ} \mathrm{C} 30 \\
\min 2.5 \% \mathrm{gel}\end{array}$ & $\begin{array}{l}\text { Lehmann et al. (2006) } \\
\text { Su et al. (2006) }\end{array}$ \\
\hline BTUB & IX & $\begin{array}{l}\text { SAG2-Fa:ACCCATCTGCGAA- GAAAACG } \\
\text { SAG2-Ra:ATTTC- GACCAGCGGGAGCAC }\end{array}$ & 411 & $\begin{array}{c}\text { Bsiel, } \\
\text { Taql }\end{array}$ & NEB4, BSA, $60^{\circ} \mathrm{C} 60 \mathrm{~min} 2.5 \% \mathrm{gel}$ & $\begin{array}{l}\text { Khan et al. (2005) } \\
\text { Su et al. (2006) }\end{array}$ \\
\hline GRA6 & $\mathrm{x}$ & $\begin{array}{l}\text { GRA6-F1:TTTCCGAG- CAGGTGACCT } \\
\text { GRA6- R1x:TCGCCGAAGAGTTGA- CATAG }\end{array}$ & 344 & Msel & NEB2, BSA, $37^{\circ} \mathrm{C} 60 \mathrm{~min} 2.5 \% \mathrm{gel}$ & $\begin{array}{l}\text { Fazaeli et al. (2000) } \\
\text { Su et al. (2006) }\end{array}$ \\
\hline SAG3 & XII & $\begin{array}{l}\text { P43S1:CAACTCTCAC- CATTCCACCC-3 } \\
\text { P43AS1:GCGCGTTGTTAGA-CAAGACA }\end{array}$ & 311 & Noil & NEB $4, \mathrm{BSA}, 37^{\circ} \mathrm{C} 60 \mathrm{~min} 2.5 \% \mathrm{gel}$ & Grigg et al. (2001) \\
\hline Apico & Plastídeo & $\begin{array}{l}\text { P43S1:CAACTCTCAC-CATTCCACCC-3 } \\
\text { P43AS1:GCGCGTTGTTAGA-CAAGACA }\end{array}$ & 640 & $\begin{array}{l}\text { Afll, } \\
\text { Ddel }\end{array}$ & $\begin{array}{c}\text { NEB2, BSA, } 37^{\circ} \mathrm{C} 60 \mathrm{~min} \\
3 \% \text { gel }\end{array}$ & Su et al. (2006) \\
\hline $\operatorname{cs} 3$ & VIla & $\begin{array}{l}\text { CS3-F:GTGTATCTCCGAGGGGGTCT CS3- } \\
\text { R:TGTGACTTCTTCGCATCGAC }\end{array}$ & 557 & $\begin{array}{l}\text { Mbol, } \\
\text { Nlalll }\end{array}$ & NEB4, BSA, $37^{\circ} \mathrm{C} 60 \mathrm{~min} 2.5 \% \mathrm{gel}$ & Khan et al. (2005) \\
\hline
\end{tabular}


Quadro 6 - Amostras de referência de Toxoplasma gondii utilizadas como controle positivo da reação de PCR/RFLP

\begin{tabular}{|c|c|c|c|c|c|c|c|c|c|c|c|c|}
\hline & & & & & Marcad & es genét & $\cos$ & & & & & \\
\hline $\begin{array}{l}\text { Genótipos de } \\
\text { referencia }\end{array}$ & SAG1* & $5^{\prime} 3^{\prime}$ SAG2 $^{\dagger}$ & Alt. SAG2 ${ }^{\S}$ & SAG3 & BTUB & GRA6 & $\mathrm{C} 22-8$ & $\mathrm{C} 29-2$ & L358 & PK1 & APICO & CS3 \\
\hline RH88 (tipo I) & 1 & 1 & 1 & 1 & 1 & 1 & 1 & 1 & 1 & 1 & 1 & 1 \\
\hline PTG (tipo II) & II ou III & II & II & II & II & II & II & II & II & II & II & II \\
\hline CTG (tipo III) & II ou III & III & III & III & III & III & III & III & III & III & III & III \\
\hline TgCgCa1 (Cougar) & 1 & II & II & III & II & II & II & $u-1$ & 1 & $u-2$ & 1 & II \\
\hline MAS & $u-1$ & 1 & II & III & III & III & $u-1$ & 1 & 1 & III & 1 & II \\
\hline TgCatBr5 & 1 & III & III & III & III & III & 1 & 1 & 1 & $u-1$ & 1 & II \\
\hline
\end{tabular}

*No locus SAG1 Não é possível distinguir entre os tipos II e III

'Marcador SAG2 baseado na terminação 5' e 3' do gene (HOWE et al., 1997)

§Novo marcador SAG2 baseado na terminação 5' da sequência do gene (SU et al., 2006) 


\subsection{Análise Estatística}

Para testar a presença de associação entre espécie do hospedeiro e a ocorrência de anticorpos contra os parasitos foi realizado o teste do Qui-quadrado. Em relação aos jumentos também foi analisada a associação entre as diferentes localidades amostradas e os valores de ocorrência de T. gondii utilizando o mesmo teste. Valores de $p \leq 0,05$ foram considerados significativos.

Os dados coletados foram analisados pelo software IBM SPSS Statistics 19 e o teste de chi quadrado foi realizado para estabelecer diferenças entre ocorrência dos agentes estudados e a espécie animal, com um nível significância $p<0,005$.

\subsection{Fluxograma do Delineamento}

O fluxograma abaixo ilustra as etapas realizadas no presente estudo. 


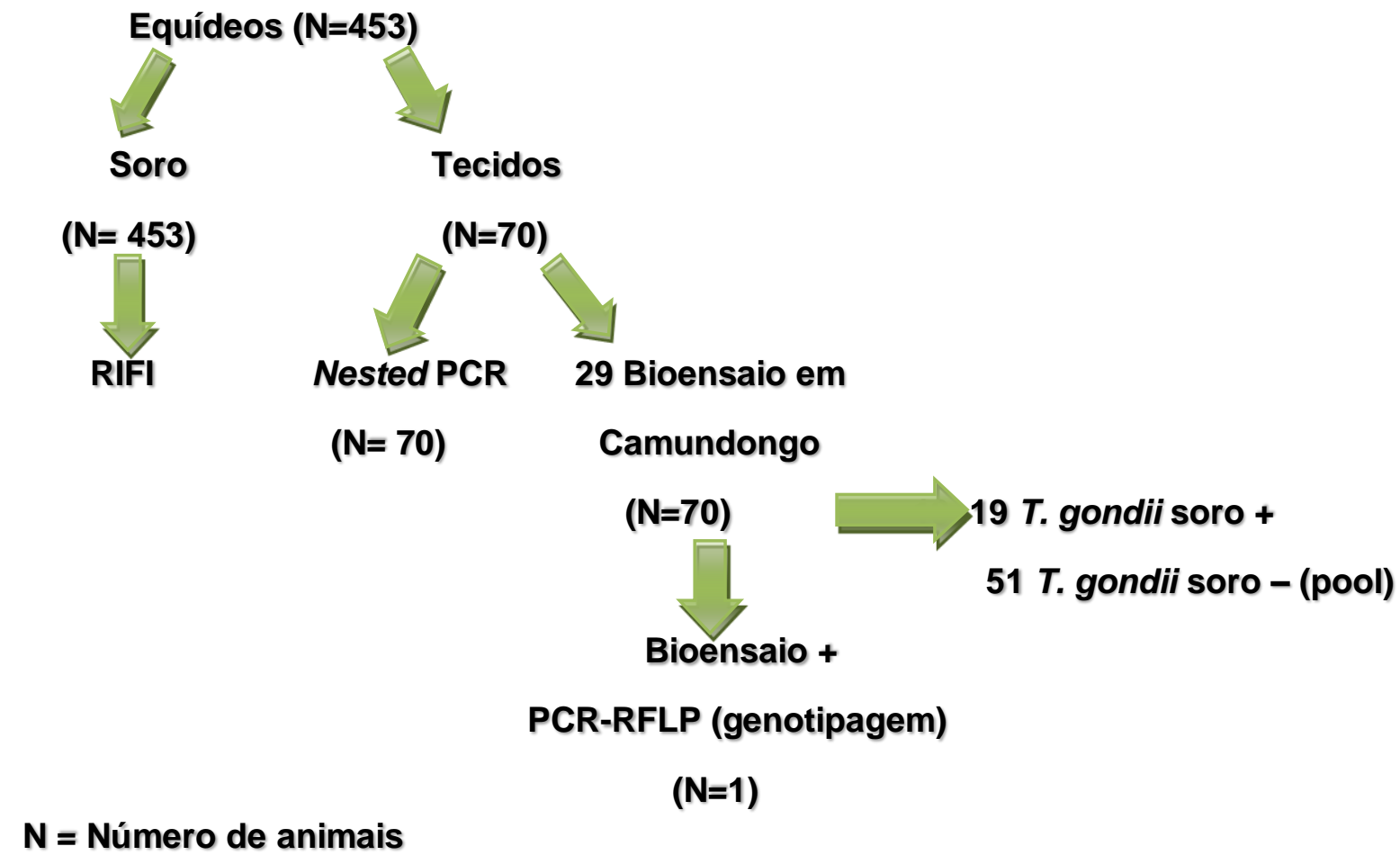




\section{RESULTADOS}

Os resultados foram divididos em análise sorológica, isolamento de $T$. gondii e análise molecular.

\subsection{Análise Sorológica}

\subsubsection{NEOSPORA SPP.}

Foram realizadas RIFI para pesquisa de anticorpos anti- Neospora spp. em 453 animais, sendo $1,75 \%$ (8) deles positivos. Os animais positivos por espécie, local e titulação encontram-se na tabela 1 e gráfico 1.

Dos 304 jumentos examinados, sete $(2,30 \%)$ foram positivos, sendo três de Petrolina, PE e quatro de Piranhas, AL. Dos 118 cavalos somente um $(0,85 \%)$ animal de Petrolina, PE, apresentou anticorpos anti- N. caninum. Nenhuma das 31 mulas examinadas foi positiva a anticorpos contra esse coccídio e nenhum animal foi positivo para Neospora spp. nos municípios de Mossoró, Patos, Araguari e Campo Maior. Em três jumentos do município de Petrolina (PE 72, 87, 88) houve positividade para ambos os agentes pesquisados.

A associação entre as espécies de hospedeiros e ocorrência de $N$. caninum não foi possível ser testada devido ao baixo número de positivos. 
Tabela 1 - Número de amostras positivas para anticorpos anti- Neospora spp. (RIFI $\geq 50$ ) segundo local de procedência, título de anticorpos e espécie examinada

\begin{tabular}{|c|c|c|c|c|c|}
\hline $\begin{array}{l}\text { ESPÉCIE } \\
\text { Município (Estado) }\end{array}$ & Examinados & Positivos & $\begin{array}{c}\text { Ocorrência } \\
\%\end{array}$ & Título & $\begin{array}{l}\text { Positivos } \\
\text { por título }\end{array}$ \\
\hline \multicolumn{6}{|l|}{ JUMENTOS } \\
\hline \multirow[t]{2}{*}{ Petrolina (PE) } & 140 & 3 & 2,14 & 50 & 2 \\
\hline & & & & 100 & 1 \\
\hline \multirow[t]{4}{*}{ Piranhas (AL) } & 85 & 4 & 4,70 & 50 & 1 \\
\hline & & & & 100 & 1 \\
\hline & & & & 400 & 1 \\
\hline & & & & 800 & 1 \\
\hline \multicolumn{6}{|l|}{ CAVALOS } \\
\hline Petrolina (PE) & 57 & 1 & 1,75 & 50 & 1 \\
\hline
\end{tabular}

Gráfico 1 - Frequência de amostras positivas por espécie animal para anticorpos antiNeospora spp. segundo município de origem dos animais

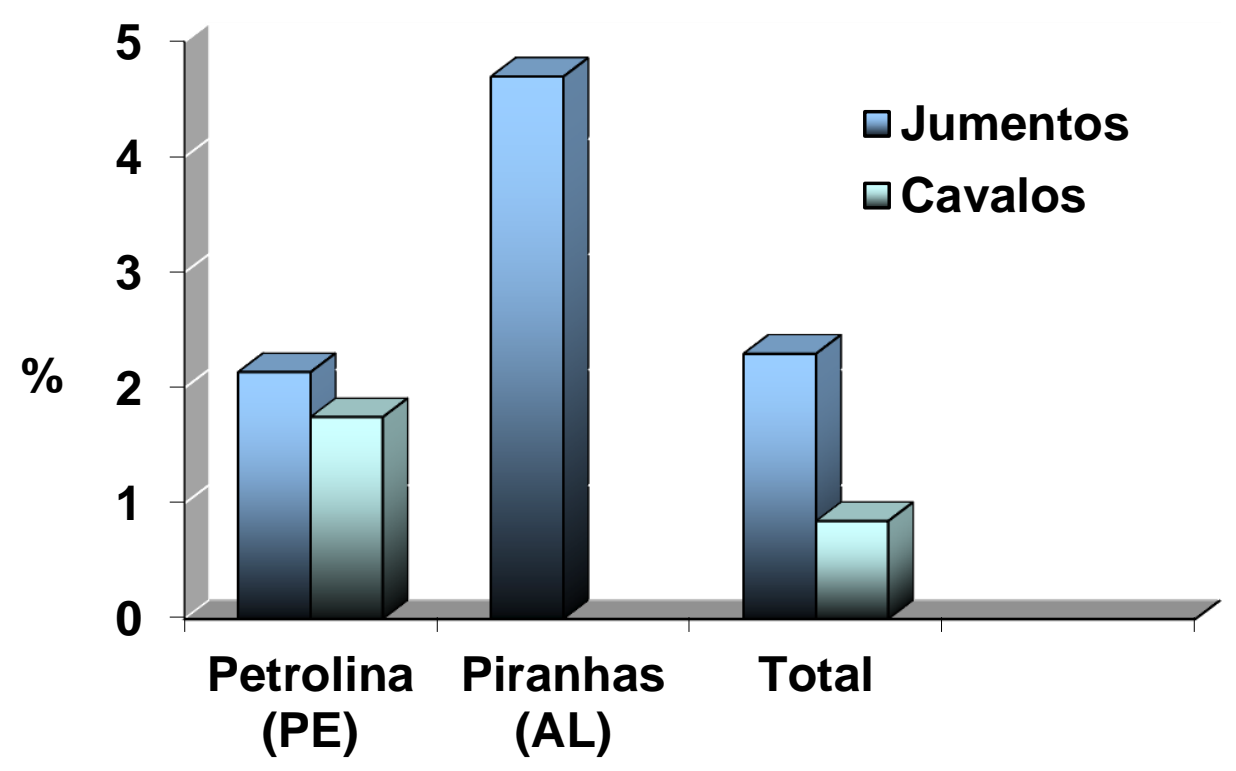




\subsubsection{T. GONDII}

Foram realizadas RIFI para pesquisa de anticorpos anti- $T$, gondii em 453 animais, sendo $28,47 \%$ (129) dos animais positivos.

Dos 304 jumentos examinados, $82(26,97 \%)$ foram soropositivos para anticorpos anti- T. gondii. Em relação aos cavalos, $32(27,11 \%)$ dos 118 examinados foram positivos e em relação às mulas, 15 (48,38\%) das 31 amostras avaliadas foram positivas. Foi encontrada associação entre a espécie do hospedeiro e a ocorrência de $T$. gondii (Qui-quadrado $=6,478$, graus de liberdade $=2$, valor de $p=$ 0,039 ), sendo que as mulas foram mais acometidas que os cavalos e jumentos. $A$ tabela 2 e o gráfico 2 apresentam a ocorrência de anticorpos anti- T. gondii por espécie animal e município de origem das amostras.

Em todos os municípios amostrados observou-se a presença de equídeos positivos a anticorpos contra $T$. gondii.

Em relação à ocorrência de anticorpos anti- $T$. gondii nos jumentos, os índices encontrados no Piauí $(81,82 \%)$ foram superiores aos observados nos outros estados ( $p \leq 0,05$ ) que foram de 15,29\% em Alagoas, 20\% na Paraíba, 28,57\% em Pernambuco e $36,84 \%$ no Rio Grande do Norte. Somente o município de Petrolina possuía as três espécies de equídeos e a análise estatística mostra haver associação com a espécie, com ocorrência mais elevada nas mulas $(p=0,019)$.

O resultado da sorologia de todos os animais positivos por sorologia, município, estado e espécie animal tanto para Neospora spp. quanto para T. gondii encontra-se no Apêndice A. 
Tabela 2 - Número de amostras positivas para anticorpos anti- T, gondi (RIFI $\geq 64$ ) segundo titulação, local de procedência e espécie examinada

\begin{tabular}{|c|c|c|c|c|c|}
\hline $\begin{array}{l}\text { ESPÉCIE } \\
\text { Município (Estado) }\end{array}$ & Examinados & Positivos & $\begin{array}{c}\text { Ocorrência } \\
\text { \% }\end{array}$ & Título & $\begin{array}{l}\text { Positivos } \\
\text { por título }\end{array}$ \\
\hline \multicolumn{6}{|l|}{ JUMENTOS } \\
\hline Campo Maior (PI) & 11 & 9 & 81,82 & 64 & 9 \\
\hline \multirow[t]{2}{*}{ Mossoró (RN) } & 38 & 14 & 36,84 & 64 & 9 \\
\hline & & & & 256 & 5 \\
\hline Patos (PB) & 30 & 6 & 20,00 & 64 & 6 \\
\hline \multirow[t]{2}{*}{ Petrolina (PE) } & 140 & 40 & 28,57 & 64 & 30 \\
\hline & & & & 256 & 10 \\
\hline \multirow[t]{2}{*}{ Piranhas (AL) } & 85 & 13 & 15,29 & 64 & 6 \\
\hline & & & & 256 & 7 \\
\hline \multicolumn{6}{|l|}{ CAVALOS } \\
\hline Araguari (MG) & 61 & 10 & 16,30 & 64 & 10 \\
\hline \multirow[t]{2}{*}{ Petrolina (PE) } & 57 & 22 & 38,50 & 64 & 15 \\
\hline & & & & 256 & 7 \\
\hline \multicolumn{6}{|l|}{ MULAS } \\
\hline \multirow[t]{2}{*}{ Petrolina (PE) } & 31 & 15 & 48,38 & 64 & 11 \\
\hline & & & & 256 & 4 \\
\hline
\end{tabular}


Gráfico 2 - Frequência de amostras positivas para anticorpos anti- $T$, gondii segundo município e espécie animal examinada

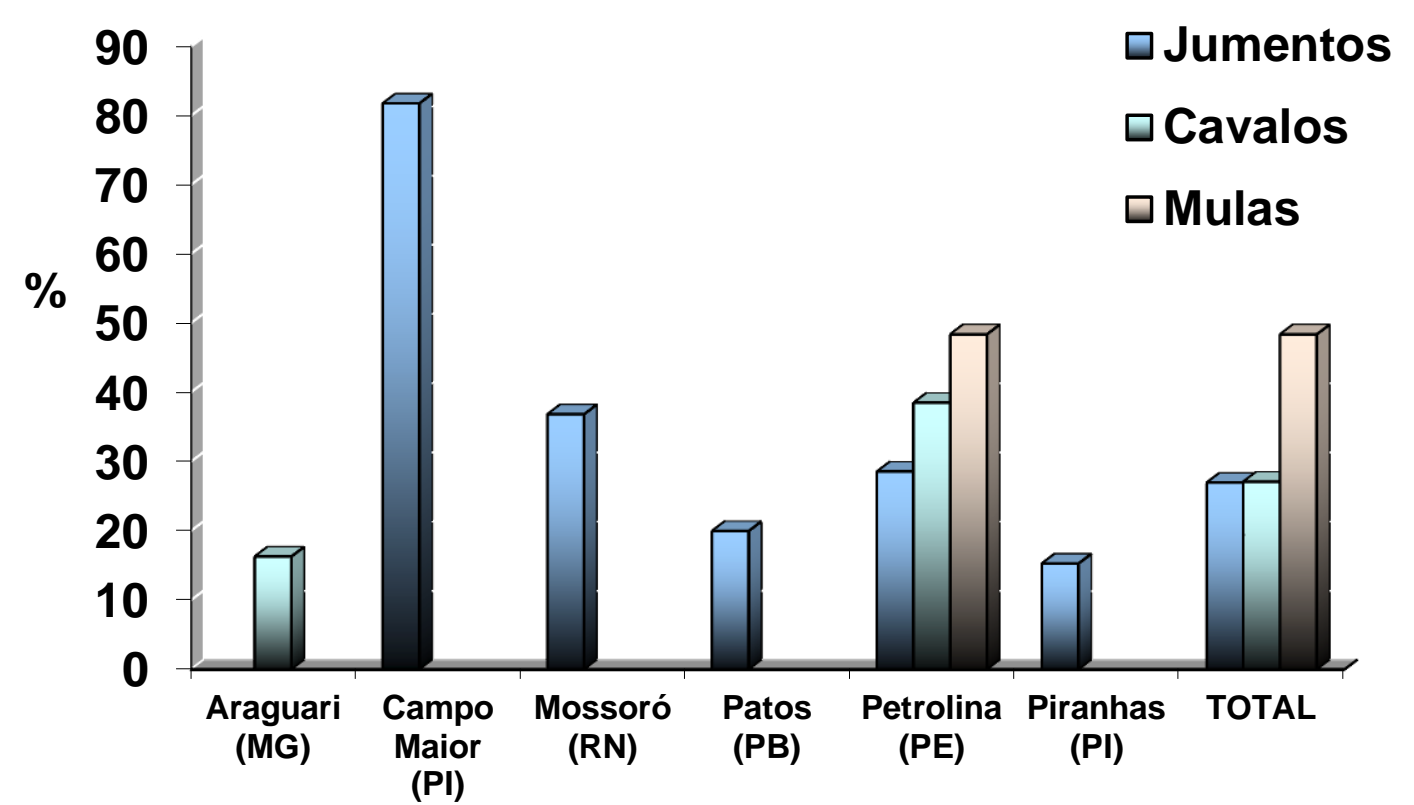

A tabela 3 o gráfico 3 apresentam a ocorrência de anticorpos anti- $T$. gondii e anti- N. caninum por espécie animal.

Tabela 3- Número de animais examinados e positivos para anticorpos anti- $T$. gondii e antiN. caninum por espécie examinada

\begin{tabular}{lcccccc}
\hline \multirow{2}{*}{ Espécie } & Examinados & \multicolumn{2}{c}{ T. gondii } & \multicolumn{2}{c}{ N. caninum } \\
\cline { 3 - 5 } & & No Positivos & $\%$ & & No Positivos & $\%$ \\
\hline JUMENTOS & 304 & 82 & 26,97 & 7 & 2,30 \\
CAVALOS & 118 & 32 & 27,11 & 1 & 0,84 \\
MULAS & 31 & 15 & 48,38 & 0 & 0,00 \\
\hline Total & 453 & 129 & 28,47 & 8 & 1,76 \\
\hline
\end{tabular}


Gráfico 3- Frequência de animais positivos para anticorpos anti- $T$, gondii e anti- Neospora spp. por espécie

T. gondii $\square$ N. caninum

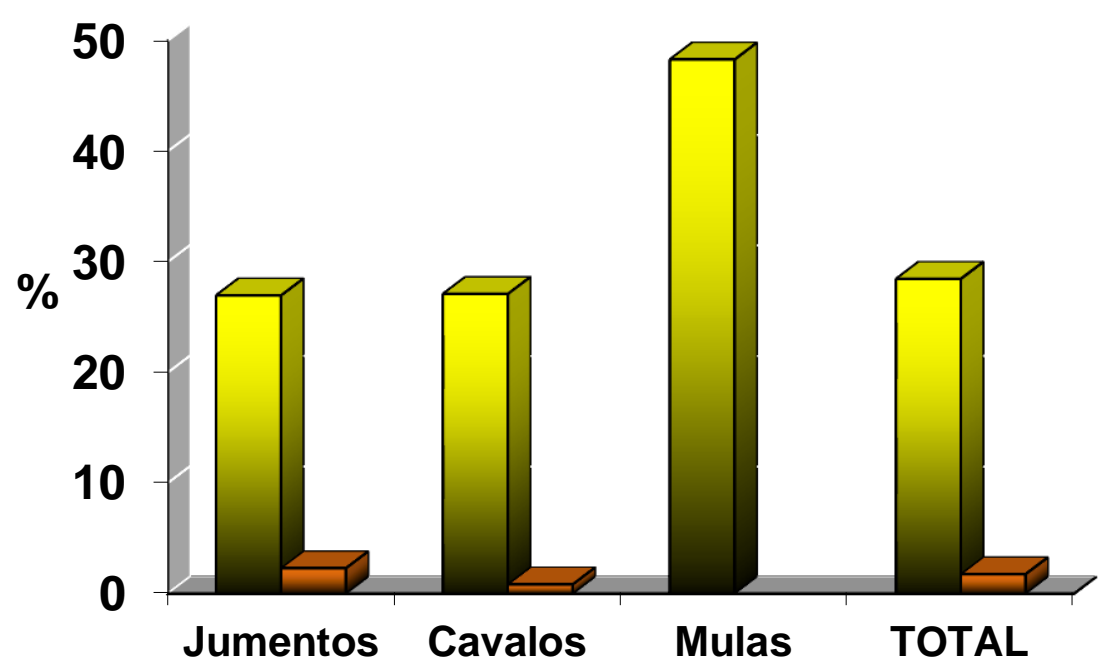

\subsection{Isolamento de T. gondii}

Somente em uma amostra, do jumento de Mossoró (Mo 6), soropositivo a anticorpos anti- T. gondii $(\mathrm{RIFI}=64)$, obteve-se isolamento de $T$. gondii pelo bioensaio em camundongos. Amostras teciduais deste animal foram inoculadas em 20 camundongos e desses somente dois, que receberam material da língua, infectaram-se e foram a óbito nos dias 16 e 17 pós-inoculação. Os outros 18 camundongos que não vieram a óbito não apresentaram anticorpos séricos e não se observou o parasita em seus tecidos, indicando que não estavam infectados. 


\subsection{Análise Molecular das Amostras Primárias}

Foi realizada a análise molecular de tecidos (amostras primárias) de 70 animais sendo 40 tecidos de cavalos ( 30 tecidos dos 10 soropositivos e 10 pools de tecidos de 51 soronegativos) e 36 tecidos de nove jumentos soropositivos. Desses animais foram examinadas alíquotas de $500 \mu \mathrm{L}$ de cada amostra, com exceção das amostras do jumento Mo 6 (coração, cérebro, língua e diafragma) que foram examinadas em duplicata, pois mesmo tendo sido isolado $T$. gondii nos camundongos infectados com tecidos desse animal, na nested- PCR os tecidos originais foram negativos.

Houve detecção molecular em uma única amostra de cavalo das 40 examinadas e correspondeu ao cavalo $\operatorname{Ar} 387$ abatido no frigorífico de Araguari.

Devido à pequena quantidade de tecido, não foi possível a obtenção de DNA suficiente para realizar o sequenciamento, sem diagnóstico confirmatório desta amostra.

\subsection{PCR- RFLP}

A caracterização genotípica foi realizada em uma amostra isolada em camundongos pelo bioensaio obtida de um jumento de Mossoró, RN.

Por meio da PCR-RFLP, foi possível a caracterização genotípica completa, isto é, a análise dos 12 marcadores, sendo eles SAG1, SAG2, ALT.SAG2, SAG3, BTUB, GRA6, c22-8, c29-2, L358, PK1, Apico e Cs3. 
A genotipagem dessa amostra evidenciou o genótipo \#60 TgCkBr220, o qual foi anteriormente descrito por Dubey et al. (2010) em uma galinha de Fernando de Noronha, PE. O resultado da caracterização genotípica do isolado está expresso na Tabela 4. 
Tabela 4 - Genótipos multilocus do isolado de jumento do Brasil obtidos pela PCR/RFLP

\begin{tabular}{|c|c|c|c|c|c|c|c|c|c|c|c|c|c|c|c|}
\hline \multirow{2}{*}{ AMOSTRA } & \multicolumn{12}{|c|}{ Genótipo pela PCR-RFLP } & \multirow{2}{*}{ Espécie } & \multirow{2}{*}{ Localização } & \multirow[b]{2}{*}{ Referência * } \\
\hline & SAG1 & SAG2 & $\begin{array}{l}\text { ALT. } \\
\text { SAG2 }\end{array}$ & SAG3 & BTUB & GRA6 & c22-8 & c29-2 & L358 & PK1 & Apico & $\operatorname{cs} 3$ & & & \\
\hline Mo6 & 1 & III & III & III & III & III & $\|$ & 1 & III & III & III & III & $\begin{array}{c}\text { Jumento } \\
\text { (Equus } \\
\text { asinus) }\end{array}$ & Mossoró-RN & $\begin{array}{l}\text { TgCkBr220 } \\
\text { Fernando de } \\
\text { Noronha - PE }\end{array}$ \\
\hline
\end{tabular}

* Dubey et al. (2010) 


\section{DISCUSSÃO}

Neste estudo 453 jumentos, mulas e cavalos foram examinados e apenas $1,7 \%$ desses foram positivos para anticorpos anti- Neospora spp. (RIFI $\geq 50$ ).

Não são muitos os estudos de soroprevalência de infecção por Neospora spp. em equídeos quando comparados com pesquisas semelhantes feitas em outras espécies de animais domésticos. Mesmo assim a comparação de resultados deve ser feita com atenção devido a diferenças nas amostragens, testes sorológicos, pontos de corte e espécies animais examinadas.

Por espécie animal os resultados do presente estudo indicam uma maior ocorrência nos jumentos $(2,3 \%)$, seguido pelos equinos $(0,85 \%)$ e nenhum dos muares examinados foi positivo para $N$. caninum. Esta diferença observada entre as espécies animais não pode ser estatisticamente analisada devido ao baixo número de animais positivos.

Mesmo assim, os valores obtidos estão dentro dos resultados de estudos feitos em diferentes regiões do país, que indicam ocorrência entre 1,6 a 47\% para equinos (HOANE et al., 2006; LOCATELLI-DITTRICH et al., 2006; VILLALOBOS et al., 2006, 2012). Fora do país estudos com as espécies estudadas também são poucos e no Alabama, Cheadle et al. (1999) encontraram valores semelhantes aos deste estudo.

Apesar da baixa ocorrência os títulos de anticorpos anti- $N$. caninum variaram de 50 a 800. O único cavalo positivo apresentou título baixo (50), entretanto dentre os jumentos três apresentaram titulação mínima (50) e nos outros três animais títulos de 100, 400 e 800 foram encontrados. Moraveji et al. (2011), no Iran, obtiveram uma soroprevalência de $32 \%$ em equinos, com títulos de 80 pelo NAT (Neospora Agglutination Test) e Dangoudoubiyam et al. (2011), na Costa Rica, encontraram valores de soroprevalência de $3,5 \%$ também em equinos. 
Em estudos de pesquisa de anticorpos anti- Neospora spp realizados no Brasil (VILLALOBOS et al., 2006) e em outras partes do mundo (DUBEY; PORTFIELD, 1986) os animais tinham histórico de perdas reprodutivas, fato que não é conhecido neste estudo e que pode estar associado à ocorrência deste coccídio.

Conforme demonstrado por Gondim et al. (2009), deve-se suspeitar de um alto percentual de reatividade sorológica cruzada entre N. caninum e N. hughesi, o que não permite a diferenciação da infecção por estes agentes utilizando-se a RIFI. Dessa forma, embora tenham sido utilizados taquizoítos de $N$. caninum na RIFI, considera-se a ocorrência para o gênero Neospora spp. devido à especificidade insuficiente da reação.

Tal qual observado em estudos com outras espécies animais que não os bovídeos, a ocorrência da infecção por $N$. caninum foi baixa, em especial quando comparada a outros coccídios como $T$. gondii, indicando que este parasito deve causar baixo impacto à sanidade dos equídeos.

Em relação a $T$. gondii foram encontrados no total $28,47 \%$ de animais positivos, sendo $26,97 \%$ dos jumentos, $27,11 \%$ dos cavalos e $48,38 \%$ das mulas, sendo esta diferença significativa $(p \leq 0,05)$ e indicando uma maior ocorrência nos muares.

Num estudo no qual também foi comparada a ocorrência de anticorpos anti- $T$. gondii em cavalos, jumentos e mulas da região nordeste, do estado da Bahia, utilizando a RIFI ( $\geq 64)$, os autores encontraram valores de 1,61\% e 1,52\% para cavalos e jumentos, respectivamente e nenhuma das 22 mulas foram positivas (MENDONÇA et al., 2001). Ainda na região nordeste (Pernambuco, Rio Grande do Norte, Paraíba e Sergipe) Oliveira et al. (2012) pesquisaram a presença de anticorpos contra $T$. gondii (RIFI $\geq 64$ ) e encontraram valores estatisticamente superiores nos jumentos $(43,2 \%)$ quando comparados as mulas (23,8\%). $\mathrm{Na}$ Espanha, Garcia Bocanegra et al. (2012) observaram 10,8\% dos equinos, 15\% de muares e $25,6 \%$ de jumentos soropositivos a anticorpos conta $T$. gondii utilizando o MAT ( $\geq 25)$ e esta diferença foi significativa com maior número de jumentos positivos 
ao agente. Estas diferenças observadas entre os diferentes estudos com estas espécies de equídeos indicam que estes estão expostos à infecção pelo $T$. gondii e apesar da baixa patogenicidade que este agente parece ter nos equídeos, natural ou experimentalmente infectados (SPOSITO FILHA et al., 1983), vale lembrar que carnes desses animais são consumidas em algumas partes do mundo, podendo funcionar como fonte de infecção de $T$. gondii aos humanos.

Apesar de alguns valores de ocorrência terem sido relativamente altos, seja em mulas como em jumentos, não há na literatura descrição de perdas reprodutivas ou outros sinais clínicos causados pelo $T$. gondii nessas espécies animais, fato que merece maiores estudos.

No presente trabalho amostras de jumentos foram obtidas de cinco Estados da região nordeste e em todos os Estados animais positivos estavam presentes, evidenciando a ampla dispersão do $T$. gondii nessa espécie na região estudada. Todas as mulas do estudo eram provenientes de Petrolina (PE) não dando para avaliar a dispersão de muares positivos na região. Entretanto quando se compara a ocorrência de anticorpos conta T. gondii nos cavalos (38,50\%), jumentos $(28,57 \%)$ e mulas $(48,38 \%)$ do mesmo município (Petrolina, PE), a ocorrência nos muares também é superior $(p<0,005)$, indicando um maior contato com as fontes de infecção do parasito nos muares. Normalmente os asininos e os muares da região estudada executam as mesmas funções, isto é, principalmente tração, não sendo possível correlacionar essa maior ocorrência nos muares com os hábitos de vida desses animais.

Vários estudos realizados no país encontraram uma ampla variação nos valores de ocorrência, de 2 a $70 \%$, para equinos de variadas regiões e, devido as diferentes técnicas, pontos de corte utilizados e amostragens distintas, comparações devem ser feitas com cautela (ISHIZUKA; MIGUEL. BROGLIATO,, 1975; SILVA et al., 1981; LARANJEIRA; ISHIZUJA; HYAKUTAKE, 1985; BRACCINI et al., 1992; GAZÊTA et al., 1997; VIDOTTO et al., 1997; GARCIA et al., 1999; NAVES; FERREIRA; COSTA., 2005; VILLALOBOS et al., 2005). 
Neste estudo, equinos só foram amostrados nos estados de Minas Gerais e Pernambuco. O valor de ocorrência e $T$. gondii observado em Petrolina (PE) foi aproximadamente o dobro daquele encontrado em Araguari (MG) e, por serem estes últimos animais de abatedouro e de finalidade zootécnica e procedências exatas desconhecidas, discutir sobre os possíveis fatores que possam ter sido responsáveis por esta maior ocorrência em Petrolina é inviável.

Turner e Savva (1991) afirmaram que $T$. gondii pode causar em equinos encefalomielite caracterizada por hiperirritabilidade, incoordenação motora, distúrbios oculares e abortamento, entretanto parece pouco comum quadros clínicos de toxoplasmose nessas espécies e todos os animais amostrados no presente estudo aparentavam estar saudáveis.

Existem poucos dados a respeito de técnicas de isolamento de Neospora spp. e $T$. gondii em animais dessas espécies. Neste estudo não foi possível o isolamento de Neospora spp. devido a impossibilidade de obtenção dos tecidos dos animais positivos.

No Egito, Shaapan e Ghazy (2007) isolaram, pelo bioensaio em camundongos e em gatos, $T$. gondii de 79 dos 150 cavalos que teriam seus tecidos utilizados para consumo humano. Al-Khalidi e Dubey (1979) também isolaram $T$. gondii de carne de cavalos americanos que seriam utilizadas para o consumo humano. Outro estudo realizado por Dubey et al. (1999), com equinos do Canadá e Estados Unidos que seriam utilizados para consumo humano, apontou uma ocorrência de anticorpos anti-T. gondii de 6,9\%.

$\mathrm{Na}$ França, três severos casos clínicos de toxoplasmose humana foram relacionados ao consumo de carne equina importada do Canadá ou Brasil (POMARES et al., 2011). Um desses três pacientes morreu com um quadro severo de toxoplasmose. Outra paciente estava grávida quando houve a infecção e a criança nasceu com toxoplasmose congênita. A terceira paciente também era uma gestante e o término da gestação foi recomendado por exames que observaram o feto com sérios problemas. Este apresentava graves alterações no cérebro, fígado e 
coração devido à presença de $T$. gondii e a gestante permaneceu sob tratamento contra o parasito por três anos. Todos os três pacientes tinham por hábito a ingestão de carne de equídeos e a análise molecular dos isolados mostrou que todos eram genótipos atípicos, nunca descritos na França ou Europa. Pesquisando o local de compra das carnes equinas observaram que o primeiro paciente, que foi a óbito, ingeriu carne de equino procedente do Canadá e a segunda paciente do Brasil. A procedência da carne ingerida pela terceira paciente não foi determinada.

Estes estudos mostram que a toxoplasmose nessa espécie também pode ser um grave problema de saúde pública, em especial nos países que tem por hábito o consumo de carne desses animais.

Dos bioensaios em camundongos realizados no presente estudo para o isolamento de $T$. gondii, dos 19 animais soropositivos examinados (nove jumentos e 10 cavalos) e do pool de 51 cavalos soronegativos, somente um isolado foi obtido de um jumento do município de Mossoró, RN, que apresentou titulo de 64 na RIFI. Dois dos cinco camundongos inoculados com tecidos de língua desse jumento tornaramse positivos a anticorpos anti- T. gondii e ambos vieram a óbito, nos dias 16 e 17 pós-inoculação. Este é o primeiro isolado de $T$. gondii obtido a partir de jumentos.

A PCR-RFLP utilizando 12 marcadores indicou que o isolado obtido já havia sido anteriormente descrito por Dubey et al. (2010) no arquipélago de Fernando de Noronha, PE, também região nordeste do Brasil, em uma galinha (\#60 TgCkBr220). No bioensaio realizado com a amostra obtida em Fernando de Noronha, todos os três camundongos inoculados se infectaram, entretanto nenhum deles foi a óbito. No presente estudo o mesmo isolado mostrou-se patogênico para camundongos. Vinte camundongos foram inoculados com quatro diferentes tecidos (5-cérebro, 5diafragma, 5-língua e 5-coração) desse jumento e somente dois se infectaram e vieram a óbito, ambos haviam recebido o mesmo tecido, língua. A baixa infecção observada nos camundongos, associada ao não encontro do DNA de $T$. gondiï nos tecidos dos animais pela nested- PCR indicam que provavelmente a quantidade de cistos teciduais, quando presente, deve ser baixa. 
É difícil inferir sobre patogenicidade de isolados baseado em mortalidade de camundongos usados em bioensaios uma vez que a dose e o estágio do parasito no inóculo é sempre desconhecida. A genotipagem do locus CS3 desse isolado revelou o alelo Tipo III, que no caso indicaria não virulência (KHAN et al., 2005; DUBEY et al., 2007; PENA et al., 2008; DUBEY et al., 2010; da SILVA et al., 2011), entretanto neste estudo, apesar do Tipo III estar presente nesse locus, houve mortalidade de dois camundongos. Vale lembrar que somente dois dos 20 camundongos inoculados infectaram-se, representando uma baixa taxa de infecção, mas alta letalidade, 100\% dos infectados.

Apesar do uso de diferentes formas de analisar a patogenicidade dos isolados, isto é, por mortalidade de camundongos ou marcadores moleculares, a correlação com as manifestações clínicas da doença ainda não são claras e nenhuma metodologia se mostrou totalmente eficiente (FRAZÃO-TEIXEIRA et al., 2011). 


\section{CONCLUSÕES}

Os resultados obtidos permitem concluir:

- Anticorpos anti-Neospora spp estão presentes em jumentos e cavalos de diferentes regiões do Brasil.

- Anticorpos anti- Toxoplasma gondii estão presentes em jumentos, mulas e cavalos de diferentes regiões do Brasil.

- Os muares examinados apresentaram maior ocorrência de anticorpos antiToxoplasma gondii quando comparados aos equinos e asininos.

- Toxoplasma gondii foi pela primeira vez isolada de um jumento, de Mossoró, $\mathrm{RN}$, e apresentou similaridade a um isolado obtido no Arquipélago de Fernando de Noronha, PE, de uma galinha. 


\section{REFERÊNCIAS}

AL-KHALID, N. W.; DUBEY, J. P. Prevalence of Toxoplasma gondii infections in horses. Journal of Parasitology, v. 65, n. 2, p. 331-334, 1979.

ALVARADO-ESQUIVEL, C.; RODRÍGUEZ-PEÑA, S.; VILLENA, I.; DUBEY, J. P. Seroprevalence of Toxoplasma gondii infection in domestic horses in Durango state, Mexico. Journal of Parasitology, v. 98, n. 5, p. 944-945, 2012.

ANDERSON, M. L.; BLANCHARD, P. C.; BARR, B. C.; DUBEY, J. P.; HOFFMAN, R. L.; CONRAD, P. A. Neospora-like protozoan infection as a major cause of abortion in California dairy cattle. Journal of the American Veterinary Medical Association, v. 198, n. 2, p. 241-244, 1991.

AUSUBEL, F.; BRENT, F.; KINGSTON, R. E.; MOORE, D. D.; SEIDMAN, J. G.; SMITH, J. A.; STRUHL, K. (Ed.). Short protocols in molecular biology. $4^{\text {th }}$ ed. New York: Wiley, 1999. Sections 2-3-2-7.

AZEVEDO, S. S.; PENA, H. F. J.; ALVES, J. A.; GUIMARÃES FILHO, A. A. M.; OLIVEIRA, R. M.; MAKSIMOV, P.; SCHARES, G.; GENNARI, S. M. Prevalence of anti-Toxoplasma gondii and anti-Neospora caninum antibodies in swine from Northeastern Brazil. Revista Brasileira de Parasitologia Veterinária, v, 19, n. 2, p. $1-5,2010$.

BARBER, J. S.; HOLMDAHL, O. J. M.; OWEN, M. R.; GUY, F.; UGGLA, A.; TREES, A. J. Characterization of the first European isolate of Neospora caninum.

Parasitology, v. 111, n. 5, p. 563-568, 1995.

BARR, B. C.; CONRAD, P. A.; BREITMEYER, R.; SVERLOW, K.; ANDERSON, M. L.; REYNOLDS, J.; CHAUVET, A. E.; DUBEY, J. P.; ARDANS, A. A. Congenital Neospora infection in calves born from cows that had previously aborted Neosporainfected fetuses: four cases (1990-1992). Journal American Veterinary Medical Association, v. 202, n. 1, p. 113-117, 1993.

BASSO, W.; HERRMANN, D. C.; CONRATHS, F. J.; PANTCHEV, N.; GLOBOKAR VRHOVEC, M.; SCHARES, G. First isolation of Neospora caninum from the faeces of a dog from Portugal. Veterinary Parasitology, v. 159, n. 2, p. 162-166, 2009.

BASSO, W.; VENTURINI, L.; VENTURINI, M. C. Prevalence of Neospora caninum infection in dogs from beef cattle farms, dairy farms, and from urban areas of Argentina. Journal of Parasitology, v. 87, n. 4, p. 906-907, 2001. 
BJERKAS, I.; MOHN, S. F.; PRESTHUS, J. Undentified cyst-forming sporozoan causing encephalomielite and myositis in dogs. Zeithschrift Fuer Parasitenkunde, v. 70, n. 2, p. 271-274, 1984.

BJÖRKMAN, C.; UGGLA, A. Serological diagnosis of Neospora caninum infection. International Journal for Parasitology, v. 29, n. 10, p.1497-1507, 1999.

BOUGHATTAS, S.; BERGAOUI, R.; ESSID, R.; AOUN, K.; BOURATBINE, A. Seroprevalence of Toxoplasma gondii infection among horses in Tunisia.

Parasitology \& Vectors, v. 4, p. 218, 2011.

BRACCINI, G. L.; CHAPLIN, E. L.; STOBBE, N. S.; ARAUJO, F. A. P.; SANTOS, N. $R$. Resultados de exames laboratoriais realizados no setor de protozoologia da Faculdade de Veterinária da Universidade Federal do Rio Grande do Sul, Porto Alegre, nos anos 1986 a 1990. Arquivos da Faculdade de Veterinária da Universidade Federal do Rio Grande do Sul (Brasil), v. 20, p. 134-149, 1992.

BRESCIANI, K. D. S.; GENNARI, S. M.; SERRANO, A. C. M.; RODRIGUES, A. A. R.; UENO, T.; FRANCO, L. G.; PERRI, S. H. V.; AMARANTE, A. F. T. Antibodies to Neospora caninum and Toxoplasma gondii in domestic cats from Brazil.

Parasitology Research, v. 100, n. 2, p. 281-285, 2007.

BUXTON, D.; MALEY, S. W.; PASTORET, P. P.; BROCHIER, B.; INNES, E. A. Examination of red fox (Vulpes vulpes) from Belgium for antibody to Neospora caninum and Toxoplasma gondii. Veterinary Record, v.14, n. 12, p. 308-309, 1997.

CAMARGO, M.E. Improved technique of Indirect Immunofluorescent for serologic diagnosis of toxoplasmosis. Revista do Instituto de Medicina Tropical, v. 6, n. 3 , p.117-118, 1964.

CHEADLE, M. A.; LINDSAY, D. S.; ROWE, S.; DYKSTRA, C. C.; WILLIAMS, M. A.; SPENCER, J. A.; TOIVIO-KINNUKAN, M. A.; LENZ, S. D.; NEWTON, J. C.;

ROLSMA, M. D.; BLAGBURN, B. L. Prevalence of antibodies to Neospora caninum in horses from Alabama and characterization of an isolate recovered from a naturally infected horse. International Journal for Parasitology, v. 29, n. 10, p.1537-1543, 1999.

CHESSUM, B. S. Reactivation of Toxoplasma oocysts production in the cat by infection with Isospora felis. British Veterinary Journal, v, 128, n. 7, p. xxxiii-xxxvi, 1972.

COSTA, K. S.; SANTOS, S. L.; UZÊDA, R. S.; PINHEIRO, A. M.; ALMEIDA, M. A. O.; ARAÚJO, F. R.; MCALLISTER, M. M.; GONDIM, L. F. P. Chickens (Gallus domesticus) are natural intermediate hosts of Neospora caninum. International Journal for Parasitology, v. 38, n. 2, p.157-159, 2008. 
CUDDON, P.; LIN, D. S.; BOWMAN, D. D.; LINDSAY, D. S.; MILLER, T. K.; DUNCAN, I. D.; DE LAHUNTA, A.; CUMMINGS, J.; SUTER, M.; COOPER, B.; KING, J. M.; DUBEY, J. P. Neospora caninum infection in English Springer Spaniel littermates: diagnostic evaluation and organism isolation. Journal of Veterinary Internal Medicine, v, 6, n. 6, p. 325-332, 1992.

CZOPOWICZ, M.; KABA, J.; SZALUS-JORDANOW, O.; NOWICKI, M.; WITKOWSKI, L.; FRYMUS, T. Seroprevalence of Toxoplasma gondii and Neospora caninum infections in goats in Poland. Veterinary Parasitology, v. 178, n. 3-4, p. 339-341, 2011.

DAFT, B. M.; BARR, B. C.; COLLINS, N.; SVERLOW, K. Neosopora encephalomyelitis and polyradiculoneuritis in an aged mare with Cushing's disease. Equine Veterinary Journal, v, 29, n. 3, p. 240-243, 1997.

DAMRIYASA, I. M.; BAUER, C.; EDELHOFER, R.; FAILING, K.; LIND, P.; PETERSEN, E.; SCHARES, G.; TENTER, A. M.; VOLMER, R.; ZAHNER, H. Crosssectional survey in pig breeding farms in Hesse, Germany: seroprevalence and risk factors of infections with Toxoplasma gondii, Sarcocystis spp. and Neospora caninum in sows. Veterinary Parasitology, v. 126, n. 3, p. 271-286, 2004.

DANGOUDOUBIYAM, S.; OLIVEIRA, J. B.; VÍQUEZ, C.; GÓMEZ-GARCÍA, A.; GONZÁLEZ, O.; ROMERO, J. J.; KWOK, O. C. H.; DUBEY, J. P.; Howe, D. K. Detection of antibodies against Sarcocystis neurona, Neospora spp., and Toxoplasma gondii in horses from Costa Rica. Journal of Parasitology, v. 97, n. 3, p. 522-524, 2011.

DA SILVA, R. C.; LANGONI, H.; SU, C.; DA SILVA, A. V. Genotypic characterization of Toxoplasma gondii in sheep from Brazilian slaughterhouses: new atypical genotypesand the clonal type II strain identified. Veterinary Parasitology, v. 175, n. 1-2, p. 173-177, 2011.

DIJKSTRA, T.; BARKEMA, H. W.; EYSKER, M.; HESSELINK, J. W.; WOUDA, W. Natural transmission routes of Neospora caninum between farm dogs and cattle. Veterinary Parasitology, v. 105, n. 2, p. 99-104, 2002.

DUBEY, J. P. Duration of immunity to shedding of Toxoplasma gondii oocysts by cats. Journal of Parasitology, v. 81, n. 3, p. 410-415, 1995.

DUBEY, J. P. Recent advances in Neospora and neosporosis. Veterinary Parasitology, v. 84, n. 3-4, p. 349-367, 1999.

DUBEY, J. P. Refinement of pepsin digestion method for isolation of Toxoplasma gondii from infected tissues. Veterinary Parasitology, v. 74, n. 1, p. 75-77, 1998.

DUBEY, J. P. Reshedding of Toxoplasma gondii by chronically infected cats. Nature, v. 262, n. 5565, p. 213-214, 1976. 
DUBEY, J. P., HATTEL, A. L.; LINDSAY, D. S.; TOPPER, M. J. Neonatal Neospora caninum infection in dogs: Isolation of the causative agent and experimental transmission. Journal of the American Veterinary Medical Association, v. 193, $n$. 10, p. 1259-1263, 1988a.

DUBEY, J. P.; BEATTIE, C. P. Toxoplasmosis of animals and man. Boca Raton: CRC Press, 1988, $220 \mathrm{p}$.

DUBEY, J. P.; CARPENTER, J. L.; SPEER, C. A.; TOPPER, M. J.; UGGLA, A. Newly recognized fatal protozoan disease of dogs. Journal of the American Veterinary and Medical Association, v. 192, n. 9, p. 1269-1285, 1988b.

DUBEY, J. P.; FRENKEL, J. K. Cyst-induced toxoplasmosis in cats. Journal of Protozoology, v. 19, n. 1, p. 155-177, 1972.

DUBEY, J. P.; FRENKEL, J. K. Feline toxoplasmosis from acutely infected mice and the development of Toxoplasma cysts. Journal of Protozoology, v. 23, n. 4, p. 537$546,1976$.

DUBEY, J. P.; FRENKEL, J. K. Immunity to feline toxoplasmosis: modification by administration of corticosteroids. Veterinary Pathology, v. 11, n. 4, p. 350-379, 1974.

DUBEY, J. P.; HOOVER E. A.; WALLS, K. W. Effect of age and sex on the acquisition of immunity to toxoplasmosis in cats. Journal of Protozoology, v. 24, n. 1, p. 184-186, 1977.

DUBEY, J. P.; JENKIS, M. C.; RAJENDRAN, C.; MISKA, K.; FERREIRA, L. R.; MARTINS, J.; KWOK, O. C. H.; CHOUDHARY, S. Gray wolf (Canis lupus) is a natural definitive host for Neospora caninum. Veterinary Parasitology, v. 181, n. 24, p. 382-387, 2011.

DUBEY, J. P.; KERBER, C. E.; GRANSTROM, D. E. Serologic prevalence of Sarcocystis neurona, Toxoplasma gondii, and Neospora caninum in horses in Brazil. Journal of the American Veterinary Medical Association, v. 215, n. 7, p. 970-972, 1999.

DUBEY, J. P.; LINDSAY, D. S. Neosporosis. Parasitology Today, Amsterdan, v. 9, n. 12, p. 452-458, 1993.

DUBEY, J. P.; LINDSAY, D. S.; ADAMS, D. S.; GAY, J.; BASZLER, T. V.; BLAGBURN, B. L.; THULLIEZ, P. Serologic responses of cattle and other animals infected with Neospora caninum. American Journal Veterinary Research, v. 57, n. 3, p. 329-326, 1996.

DUBEY, J. P.; MILLER, N. L.; FRENKEL, J. K. Characterization of the new fecal form of Toxoplasma gondii. Journal of Parasitology, v. 56, n. 3, p. 447-456, 1970a. 
DUBEY, J. P.; MILLER, N. L.; FRENKEL, J. K. The Toxoplasma gondii oocyst from cat faeces. Journal of Experimental Medicine v. 132, n. 4, p. 636-662, 1970 b.

DUBEY, J. P.; PORTFIELD, M. L. Toxoplasma like-sporozoa in an aborted equine fetus. Journal of the American Veterinary Medical Association, Schaumburg, $v$, 11, n. 1, p. 1312-1313, 1986.

DUBEY, J. P.; RAJENDRAN, C.; COSTA, D. G. C.; FERREIRA, L. R.; KWOK, O. C. H.; QU, D.; SU, C.; MARVULO, M. F. V.; ALVES, L. C.; MOTA, R. A.; SILVA, J. C. R. New Toxoplasma gondii Genotyped Isolated from free-range-chickens from the Fernando de Noronha, Brazil: Unexpected Findings. Journal of Parasitology, v, 96, n. 4, p. 709-712, 2010.

DUBEY, J. P.; ROMAND, S.; THULLIEZ, P.; KWOK, O. C.; SHEN, S. K.; GAMBLE, H. R. Prevalence of antibodies to Neospora caninum in horses in North America. Journal of Parasitology, v. 85, n. 5, p. 968-969, 1999.

DUBEY, J. P.; SUNDAR, N.; GENNARI, S. M.; MINERVINO, A. H. H.; FARIAS, N. A. R.; RUAS, J. L.; DOS SANTOS, T. R. B.; CAVALCANTE, G. T.; KWOK, O. C. H.; $\mathrm{SU}, \mathrm{V}$. Biologic and genetic comparison of Toxoplasma gondii isolates in free-range chickens from the northern Pará state and the southern state Rio Grande do Sul, Brazil revealed highly diverse and dintinct parasite populations. Veterinary Parasitology, v. 143, n. 2, p. 182-188, 2007.

DUBEY, J. P.; BARR, B. C.; BARTA, J. R.; BJERKAS, I.; BJORJKMAN, C.; BLAGBURN, B. L.; BOWMAN, D. D.; BUXTON, D.; ELLIS, J. T.; GOTTSTEIN, B.; HEMPHILL, A.; HILL, D. E.; HOWE, D. K.; JENKINS, M. C.; KOBAYASHI, Y.; KOUDELA, B.; MARSH, A. E.; MATTSSON, J. G.; MCALLISTER, M. M.; MODRY, D.; OMATA, Y.; SIBLEY, L. D.; SPEER, C. A.; TREES, A. J.; UGGLA, A.; UPTON, S. J.; WILLIAMS, D. J. L.; LINDSAY, D. S. Redescription of Neospora caninum and its differentiation from related coccidian. International Journal of Parasitology, v. 32, n. 8, p. 929-946, 2002.

DUBEY, J. P.; BARR, B. C.; BARTA, J. R.; BJERSKAS, I; BJORKMAN, C.; HARTLEY, W. J.; LINDSAY, D. S.; TOPPER, M. J. Fatal congenital Neospora caninum infection in a lamb. Journal of Parasitology, v. 76, n. 1, p. 127-30, 1990.

EIRAS, C.; ARNAIZ, I.; ALVAREZ-GARCIA, G.; ORTEGA-MORA, L. M.; SANJUÁNL, M. L.; YUS, E.; DIÉGUES, F. J. Neospora caninum seroprevalence in dairy and beef cattle from the northwest region of Spain, Galicia. Preventive Veterinary Medicine, v. 98, n. 2-3, p. 128-132, 2011.

FAZAELI, A.; CARTER, P. E.; PENNINGTON, T. H. Intergenic spacer (IGS) polymorphism: a new genetic marker for differenciation of Toxoplasma gondii strains and Neospora caninum. Journal of Parasitology, v. 86, n. 4, p. 716-723, 2000. 
FERROGLIO, E.; GUISO, M.; PASINO, M.; ACOSSATO, A.; TRISCIUOGLIO, A. Antibodies to Neospora caninum in stray cats from north Italy. Veterinary Parasitology, v. 131, n. 1-2, p. 31-34, 2005.

FIGLIUOLO, L. P. C.; KASAI, N.; RAGOZO, A. M. A.; DE PAULA, V. S. O.; DIAS, R. A.; SOUZA, S. L. P.; GENNARI, S. M. Prevalence of anti- Toxoplasma gondii and anti-Neospora caninum antibodies in ovine from São Paulo State, Brazil. Veterinary Parasitology, v. 123, n. 3-4, p. 161-166, 2004.

FINNO, C. J.; EATON, J. S.; ALEMAN, M.; HOLLINGSWORTH, S. R. Equine protozoal myeloencephalitis due to Neospora hughesi and equine motor neuron disease in a mule. Veterinary Ophthalmology, v. 13, n. 4, p. 259-265, 2010.

FRAZÃO-TEIXEIRA, E.; SUNDAR, N.; DUBEY, J. P.; GRIGG, M. E.; DE OLIVEIRA, F. C. R. Multi-locus DNA sequencing of Toxoplasma gondii isolated from Brazilian pigs identifies genetically divergent strains. Veterinary Parasitology, v. 175, n. 1-2, p. 33-39, 2011.

FRENKEL, J. K.; DUBEY, J. P.; MILLER, N. L. Toxoplasma gondii in cats: fecal stages identified as coccidian oocysts. Science, v. 167, n. 3919, p. 893-896, 1970.

FUJII, T. U.; KASAI, N.; NISHI, S. M.; DUBEY, J. P.; GENNARI, S. M. Seroprevalence of Neospora caninum in female water buffaloes (Bubalus bubalis) from the southeastern region of Brazil. Veterinary Parasitology, v. 99, n. 4, p. 331$334,2001$.

GARCIA, J. L.; NAVARRO, I. T.; OGAWA, L.; DE OLIVEIRA, R. L. Soroprevalência do Toxoplasma gondii em suínos, bovinos, ovinos e equinos, e sua correlação com humanos, felinos e caninos oriundos de propriedades rurais do norte do Paraná, Brasil. Ciência Rural, v. 29, n. 1, p. 91-97, 1999.

GARCIA-BOCANEGRA, I.; CABEZÓN, O.; ARENAS-MONTES, A.; CARBONERO, A.; DUBEY, J. P.; PEREA, A.; ALMERÍA, S. Seroprevalence of Toxoplasma gondii in equids from Southern Spain. International Parasitology, v. 61, n. 3, p. 421-424, 2012.

GAZÊTA, G. S.; DUTRA, A. E. A.; NORBERG, A. N.; SERRA-FEIRE, N. M.; SOUZA, W. J. S.; AMORIM, M.; LOPES, L. M. S. Frequência de anticorpos anti-Toxoplasma gondii em soros de equinos do Rio de Janeiro, Brasil. Revista Brasileira de parasitologia Veterinária, v, 6, n. 1. p. 97-99, 1997.

GENNARI, S. M.; Rodrigues, A. A. R.; VIANNA, R. B.; CARDOSO, E. C. Occurrence of anti-Neospora caninum antibodies in water buffaloes (Bubalus bubalis) from the northern region of Brazil. Veterinary Parasitology, v. 134, n. 1-2, p. 169-171, 2005. 
GONDIM, L. F. P.; LINDSAY, D. S.; MCALLISTER, M. M. Canine and bovine Neospora caninum control sera examined for cross-reactivity using Neospora caninum and Neospora hughesi Indirect Fluorescent Antibody tests. Journal of Parasitology, v. 95, n. 1, p. 86-88, 2009.

GONDIM, L. F. P.; MCALLISTER, M. M.; PITT, W. C.; ZEMLICKA, D. E. Coyotes (Canis latrans) are definitive hosts of Neospora caninum. International Journal for Parasitology, v. 34, n. 2, p. 159-161, 2004.

GONDIM, L. F. P.; PINHEIRO, A. M.; SANTOS, P. O.; JESUS, E. E.; RIBEIRO, M. B.; FERNANDES, H. S.; ALMEIDA, M. A.; FREIRE, S. M.; MEYER, R.; MCALLISTER, M. M. Isolation of Neospora caninum from the brain of a naturally infected dog, and production of encysted bradyzoites in gerbils. Veterinary Parasitology, v. 101, n. 1, p. 1-7, 2001.

GRAY, M. L.; HARMON, B. G.; SALES, L.; DUBEY, J. P. Visceral neosporosis in a 10-year-old horse. Journal of Veterinary Diagnosis Investigation, v. 8, n. 1, p. 130-133, 1996.

GRIGG, M. E.; GANATRA, J.; BOOTHROYD, J. C.; MARGOLIS, T. P. Unusual abundance of atypical strains associated with human ocular toxoplasmosis. Journal of Infectious Diseases, v. 184, n. 5, p. 633-639, 2001.

HÄSSIG, M.; SAGER, H.; REITT, K.; ZIEGLER, D.; STRABEL, D.; GTTSTEIN, B. Neospora caninum in sheep: a herd case report. Veterinary Parasitology, v. 117, n. 3, p. 213-220, 2003.

HELMICK, B.; OTTER, A.; MCGARRY, J.; BUXTON, D. Serological investigation of aborted sheep and pigs for infection by Neospora caninum. Research Veterinary Science, v. 73, n. 2, p. 187-189, 2002.

HILALI, M.; ROMAND, S.; THULLIEZ, P.; KWOK, O. C.; DUBEY, J. P. Prevalence of Neospora caninum and Toxoplasma gondii antibodies in sera from camels from Egypt. Veterinary Parasitology, v. 75, n. 2-3, p. 269-271, 1998.

HOANE, J. S.; GENNARI, S. M.; DUBEY, J. P.; RIBEIRO, M. G.; BORGES, A. S.; YAI, L. E. O.; AGUIAR, D. M.; CAVALCANTE, G. T.; BONESI, G. L.; HOWE, D. K. Prevalence of Sarcocystis neurona and Neospora spp. infection in horses from Brazil based on presence of serum antibodies to parasite surface antigen. Veterinary Parasitology, v, 136, n. 2, p. 155-159, 2006.

HOWE, D.K.; HONORÉ, S.; DEROUIN, F.; SIBLEY, L. D. Determination of genotypes of Toxoplasma gondii strains isolated from patients with toxoplasmosis. Journal of Clinical Microbiology, v. 35, p. 1411-1414, 1997. 
IBGE. PPM 2010. Disponível em:<http://www.ibge.gov.br, 2009>. Acesso em: 06 de janeiro de 2012.

ISHIZUKA, M. M.; MIGUEL, O.; BROGLIATO, D. F. Avaliação da prevalência de anticorpos anti-Toxoplasma gondii em equinos PSI clinicamente normais. Revista da Faculdade de Medicina Veterinária e Zootecnia da Universidade de São Paulo, v. 12, n. 7, p. 288-292, 1975.

KHAN, A.; TAYLOR, S.; SU, C.; MACKEY, A. J.; BOYLE, J.; COLE, R.; GLOVER, D.; TANG, K.; PAULSEN, I. T.; BERRIMAN, M.; BOOTHROYD, J. C.; PFEFFERKORN, E. R.; DUBEY, J. P.; AJIOKA, J. W.; ROSS, D. S.; WOOTTON, J. C.; SIBLEY, L. D. Composite genome map and recombination parameters derived from three archetypal lineages of Toxoplasma gondii. Nucleic Acids Research, v. 33, n. 9, p. 2980-2992, 2005.

KING, J. S.; SLAPETA, J.; JENKINS, J. D.; SARWAT, E. AL-QASSAB.; ELLIS, J. T.; WINDSOR, P. A. Australian dingoes are definitive hosts of Neospora caninum. International Journal for Parasitology, v. 40, n. 8, p. 945-950, 2010.

LARANGEIRA, N. L.; ISHIZUKA, M. M.; HYAKUTAKE, S. Prevalência da toxoplasmose equina avaliada pela técnica da imunofluorescência indireta, Mato Grosso do Sul, Brasil. Boletin de la Oficina sanitária Panamericana, v. 99, n. 2, p. 158-162, 1985.

LEHMANN, T.; MARCET, P. L.; GRAHAM, D. H.; DAHL, E. R.; DUBEY; J. P. Globalization and the population structure of Toxoplasma gondii. Proceedings of the National Academy of Sciences of the United States of America. v. 103, n. 30, p. 11423-11428, 2006.

LINDSAY, D. S.; BLAGBURN, B. L.; DUBEY, J. P. Feline toxoplasmosis and the importance of the Toxoplasma gondii oocyst. Compendium on Continuing Education for the Practicing Veterinarian, v. 19, n. 4, p. 448-461, 1997.

LINDSAY, D. S.; DUBEY, J. P.; DUNCAN, R, B. Confirmation that the dog is a definitive host for Neospora caninum. Veterinary Parasitology, v. 82, n. 4, p. 327333, 1999.

LINDSAY, D. S.; STEINBERG, H.; DUBIELZIG, R. R.; SEMRAD, S. D.; KONKLE, D. M.; MILLER, P. E.; BLAGBURG, B. L. Central nervous system neosporosis in a foal. Journal of Veterinary Diagnosis Investigation, v, 8, n. 4, p. 507-510, 1996.

LOCATELLI-DITTRICH, R.; DITTRICH, J. R.; RICHARTZ, R. R. T. B.; GASINO JOINEAU, M. E.; JOINEAU, J,; ANTUNES, R. D.; PINCKNEY.; DECONTO, I.; HOFFMANN, D. C. S.; THOMAZ-SOCCOL, V. Investigation of Neospora sp. and Toxoplasma gondii antibodies in mares and in precolostral foals from Parana State, Southern Brazil. Veterinary Parasitology, v. 135, n. 3-4, p. 215-221, 2006. 
MACRUZ, R.; LENCI, O.; ISHIZUKA, M. M.; MIGUEL, O. Toxoplasmose em equinos PSI: estudo sorológico. Revista da faculdade de Medicina Veterinária e Zootecnia da Universidade de São Paulo, v. 12, n. 7, p. 277-287, 1975.

MAPA. Equinos. Disponível em: <http://www.agricultura.gov.br, 2010>. Acesso em: 20 de março de 2012.

MARQUES, F. A. C.; HEADLY, A. S.; PEREIRA, V. F.; TARODA, A.; BARROS, L. D.; CUNHA, I. A. L.; MUNHOZ, K.; BUGNI, F. M.; ZULPO, D. L.; IGARASHI, M.; VIDOTTO, O.; JUNIOPR, J. S. G.; GARCIA, J. L. Neospora caninum: evaluation of vertical transmission in slaughtered beef cows (Bos indicus). Parasitology Research, v. 108, n. 4, p. 1015-1019, 2011.

MARSH, A. E.; BARR, B. C.; MADIGAN, J.; LAKRITZ, J.; NORDHAUSEN, R.; CONRAD, P. A. Neosporosis as a cause of equine protozoal myeloencephalitis. Journal of the American Medical Association, v. 209, n. 11, p. 1907-1913, 1996.

MARSH, A. E.; BARR, B.C.; PACKHAM, A. E.; CONRAD, P. A. Description of a new Neospora species (Protozoa: Apicomplexa: Sarcocystidae). Journal of Parasitology, v. 84, n. 5, p. 983-991, 1998.

MCALLISTER, M. M.; DUBEY, J. P.; LINDSAY, D. S.; JOLLEY, W. R.; WILLS, R. A.; MCGUIRE, A. M. Dogs are definitive hosts of Neospora caninum. International Journal of Parasitology, v. 28, n. 9, p. 1473-1479, 1998.

MENDONÇA, A. O.; CERQUEIRA, E. J. L.; ARAÚJO, W. N.; MORAES-SILVA, E.; SHIMABUKURO, F. H.; SARKIS, D. T.; SHERLOCH, I.; LANGONI, H. Inquérito sorológico para toxoplasmose em equídeos procedentes de duas regiões do estado da Bahia, Brasil. Semina: Ciências Agrárias, v. 22, n. 2, p. 115-118, 2001.

MORAVEJI, M.; HOSSEINI, M. H.; AMRABADI, O.; RAHIMIAN, A.; NAMAZI, F.; NAMAVARI, M. Seroprevalence of Neospora spp, in horses in South of Iran. Tropical Biomedicine, v. 28, n. 3, p. 514-517, 2011.

NAGULESWARAN, A.; HEMPHILL, A.; RAJAPAKSE, R. P. V. J.; SAGER, H. Elaboration of a crude antigen ELISA for serodiagnosis of caprine neosporosis: validation of the test by detection of Neospora caninum-specific antibodies in goats from Sri Lanka. Veterinary Parasitology, v.126, n. 3, p. 257-262, 2004.

NAVES, C. S.; FERREIRA, F. S. R.; COSTA, G. H. N. Soroprevalência da toxoplasmose em equinos da raça Mangalarga Marchador no município de Uberlândia, Minas Gerais. Veterinária Notícias, Uberlândia, v, 11, p. 45-52, 2005.

NICOLLE, M. M. C.; MANCEAUX, L. Sur un protozoaire nouveau du gondi. Comptes Rendus Hebdomadaires des Séances de l'Academie des Sciences, Paris, v. 148, p. 369-372, 1909. 
NICOLLE, M. M. C.; MANCEAUX, L. Sur une infectivo à corps de Leishmann (ou organisms voisins) du gondi. Comptes Rendus Hebdomadaires des Séances de l'Academie des Sciences, Paris, v, 147, p. 763-766, 1908.

PARÉ, J.; HIETALA, S. K.; THURMOND, M. C. Interpretation of an indirect fluorescent antibody test for diagnosis of Neospora sp. infection in cattle. Journal of Veterinary Diagnostic Investigation, Columbia, v. 7, n. 2, p. 273-275, 1995.

PENA, H. F. J.; SOARES, R. M.; RAGOZO, A. M. A.; MONTEIRO, R. M.; YAI, L. E. O.; NISHI, S. M.; GENNARI, S. M. Isolation and molecular detection of Neospora caninum from naturally infected sheep from Brazil. Veterinary Parasitology, v. 147, n. 1-2, p. 61-66, 2007.

PENA, H. F. J.; GENNARI, S. M.; DUBEY, J. P.; SU, C. Population structure and mouse-virulence of Toxoplasma gondii in Brazil. International Journal for Parasitology, v. 38, n. 5, p. 561-569, 2008.

PETERS, M.; WAGNER, F.; SCHARES, G. Canine neosporosis: clinical and pathological findings and first isolation of Neospora caninum in Germany. Parasitology Research, v. 86, n. 1, p.1-7, 2000.

POMARES, C.; AJZEMBERG, D.; BORNARD, L.; BERNARDIN, G.; HASSEINE, L.; DARDÉ, M. L.; MARTY, P. Toxoplasmosis and horse meat, France. Emerging Infectious Diseases, v. 17, n. 7, p. 1327-1328, 2011.

RODRIGUES, A. A. R.; GENNARI, S. M.; AGUIAR, D. M.; SREEKUMAR, C.; HILL, D.; MISKA, K. B.; VIANNA, M. C. B.; DUBEY, J. P. Shedding of Neospora caninum oocysts by dogs fed tissues from naturally infected water buffaloes (Bubalus bubalis) from Brazil. Veterinary Parasitology, v. 124, n. 3-4, p. 139-150, 2004.

ROMANELLI, P. R.; FREIRE, R. L.; VIDOTTO, O.; MARANA, E. R. M.; OGAWA, L.; DEPAULA, V. S. O.; GARCIA, J. L.; NAVARRO, I. T. Prevalence of Neospora caninum and Toxoplasma gondii in sheep and dogs from Guarapuava farms, Paraná State, Brazil. Research Veterinary Science, v. 82, n. 2, p. 202-207, 2007.

ROSSI, G. F.; CABRAL, D. D.; RIBEIRO, D. P.; PAJUABA, A. C. A. M.; CORREAA, R. R.; MOREIRA, R. Q.; MINEO, T. W. P.; MINEO, J. R.; SILVA, D. A. O. Evaluation of Toxoplasma gondii and Neospora caninum infections in sheep from Uberlândia, Minas Gerais State, Brazil, by different serological methods. Veterinary Parasitology, v. 175, n. 3-4, p. 252-259, 2011.

SADREBAZZAZ, A.; HADDADZADEH, H.; SHAYAN, P. Seroprevalence of Neospora caninum and Toxoplasma gondii in camels (Camelus dromedarius) in Mashhad, Iran. Parasitology Research, v. 98, n. 6, p. 600-601, 2006.

SHAAPAN, R. M.; GHAZY, A. A. Isolation of Toxoplasma gondii from Horse Meat in Egypt. Pakistan Journal of Biological Sciences, v. 10, n. 1, p. 174-177, 2007. 
SILVA, N. R. S.; CHAPLIN, E. L.; ARAÚJO, F. A. P.; PEREIRA, R. A. P. Prevalência de anticorpos toxoplásmicos em soros de equinos no município de Porto Alegre, RS. Arquivos da Faculdade de Veterinária da UFRGS, v, 9, p. 105-107, 1981.

SLAPETA, J. P.; KOPUDELA, B.; VOTYPKA, J.; MODRY, D.; HOREJS, R.; LUKES, $\mathrm{J}$. Coprodiagnosis of Hammondia heydorni in dogs by PCR based amplification of ITS-1 rRNA: differentiation from morphologically indistinguishable oocysts of Neospora caninum. Veterinary Journal, v. 163, n. 2, p. 147-154, 2002.

SOARES, R. M.; LOPES, E. G.; KEID, L. B.; SERCUNDES, M. K.; MARTINS, J.; RICHTZENHAIN, L. J. Identification of Hammondia heydorni oocysts by hemingnested-PCR (Hn PCR-AP 10) based on the Hammondia heydorni RAPD fragment AP 10. Veterinary Parasitology, v, 175, n. 1-2, p. 168-172, 2011.

SPLENDORE, A. Un nuovo protozoa parassita de'conigli incontrato nelle lesioni anatomiche d'une malatti che ricorda in molti punti il kala-azar dell'umo. Nota preliminaire pel. Revista da Sociedade Scientifica, São Paulo, v. 3, p. 109-112, 1908.

SPOSITO FILHA, E.; AMARAL, V.; MACRUZ, R.; REBOUÇAS, M. M.; SANTOS, S. M.; BORGO, F. Infecção Experimental de Equinos com Taquizoítos de Toxoplasma gondii. Revista Brasileira de Parasitologia Veterinária, v. 1, n. 1, p. 51-54, 1992.

STIEVE, E.; BECKMEN, K.; KANIA, S.; WIDNER, A.; PATTON, S. Neospora caninum and Toxoplasma gondii antibody prevalence in Alaska wildlife. Journal of Wildlife diseases, v. 46, n. 2, p. 348-355, 2010.

SU, C.; ZHANG, X.; DUBEY, J. P. Genotyping of Toxoplasma gondii by multilocus PCR-RFLP markers: a high resolution and simple method for identification of parasites. International Journal for Parasitology, v. 36, n. 7, p. 841-848, 2006.

THURMOND, M. C.; HIETALA, S. K.; BLANCHARD, P. C. Herd based diagnosis of Neospora caninum-induced endemic and epidemic abortion in cows and evidence for congenital and postnatal infection. Journal of Veterinary Diagnostic Investigation, v. 9, n. 1, p. 44-49, 1997.

TIEMANN, J. C. H.; SOUZA, S. L. P.; RODRIGUES, A. A. R.; DUARTE, J. M. B.; GENNARI, S. M. Environmental effect on the occurrence of anti-Neospora caninum antibodies in pampas-deer (Ozotoceros bezoarticus). Veterinary Parasitology, v. 134, n. 1-2, p. 73-76, 2005.

TORRES, A. P.; JARDIM, W. R. Criação do cavalo e de outros equídeos. 3. ed. São Paulo: Nobel, 1985. p. 431-479.

TURNER, C. B.; SAVVA, D. Detection of Toxoplasma gondii in equine eyes. Veterinary Record, v. 129, n. 6, p. 128, 1991. 
VIANNA, M. C. B.; SREEKUMAR, C.; MISKA, K. B.; HILL, D. E.; DUBEY, J. P. Isolation of Neospora caninum from naturally infected white- tailed deer (Odocoileus virginianus). Veterinary Parasitology, v. 129, n. 3-4, p. 253-257, 2005.

VIDOTTO, O.; KANO, F. S.; FREIRE, R. L.; MITSUKA, R.; OGAWA, L.; BANESI, G.; NAVARRO, I. T.; FRANCISCON, F. S. G. Ocorrência de anticorpos anti-Toxoplasma gondii em eqüinos procedentes de quatro estados (SP. PR, MS e MT) abatidos em Apucarana, PR. Semina: Ciências Agrárias, v. 18, n. 1, p. 9-13, 1997.

VILLALOBOS, E. M. C.; FURMAN, K. E.; LARA, M. C. C. S. H.; CUNHA, E. M. S.; FINGER, M. A.; BUSCH, A. P. B.; BARROS FILHO, I. R.; DECONTO, I.; DORNBUSCH, P. T.; BIONDO, A. W. Detection of Neospora spp. Antibodies in cart horses from urban areas of Curitiba, Southern Brazil. Revista Brasileira de Parasitologia Veterinária, v, 21, n. 1, p. 68-70, 2012.

VILLALOBOS, E. M. C.; LARA, M. C. C. S. H. L.; CUNHA, E. M. S.; SOARES, R. M. Ocorrência de anticorpos anti-Toxoplasma gondii em soro de equídeos oriundos de propriedades da região do vale do Ribeira, Estado de São Paulo e abatidos em matadouro no Estado do Paraná. Arquivos do Instituto Biológico, v. 72, p. 24, 2005.

VILLALOBOS, E. M. C.; UENO, T. E. H.; DE SOUZA, S. L. P.; CUNHA, E. M. S.; LARA, M. C. C. S. H.; GENNARI, S. M.; SOARES, R. M. Association between the presence of serum antibodies against Neospora spp. and fetal loss in equines. Veterinary Parasitology, v. 142, n. 3-4, p. 372-375, 2006.

VOGEL, F. S. F.; ARENHAR, S.; BAUERMANN, F. V. Anticorpos anti-Neospora caninum em bovinos, ovinos e Bubalinos no Estado do Rio Grande do Sul. Ciência Rural, v. 36, n. 6, p. 1948-1951, 2006.

WALSH, C. P.; DUNCAN, R. H.; ZAJAC, A. M.; BLAGBURN, B. L.; LINDSAY, D. S. Neospora hughesi : experimental infections in mice, gerbils and dogs. Veterinary Parasitology, v. 92, n. 2, p. 119-128, 2000.

WOBESER, B. K.; GODSON, D. L.; REJKMANEK, D.; DOWLING, P. Equine protozoal myeloencephalitis caused by Neospora hughesi in an adult horse in Saskatchewan. Canadian Veterinary Journal, v. 50, n. 8, p. 851-853, 2009.

XIA, H. Y.; ZHOU, D. H.; JIA, K.; ZENG, X. B.; ZHANG, D. W.; SHE, L. X.; LIN, R. Q.; YUAN, Z. G.; LI, S. J.; ZHU, X. Q. Seroprevalence of Neospora caninum infection in dairy cattle of Southern China. Journal of Parasitology, v. 97, n. 1, p. 172-173, 2011. 
YAI, L. E. O.; CAÑÓN-FRANCO, W. A.; GERALDI, V. C.; SUMMA, M. E.;

CAMARGO, M. C.; DUBEY, J. P.; GENNARI, S. M. Seroprevalence of Neospora caninum and Toxoplasma gondii antibodies in the South American opossum (Didelphis marsupialis) from the city of São Paulo, Brazil. Journal of Parasitology, v. 89, n. 4 , p. 870-871, 2003.

YAI, L. E. O.; RAGOZO, A. M. A.; CAÑON-FRANCO, W. A.; DUBEY, J. P.; GENNARI, S. M. Occurrence of Neospora caninum antibodies in capybaras (Hydrochaeris hydrochaeris) from São Paulo State, Brazil. Journal of Parasitology, v. 94, n. 3, p. 766, 2008. 


\section{APÊNDICES}

Apêndice A-Sorologia para Neospora spp.e Toxoplasma gondii dos animais por espécie, estado e município

\begin{tabular}{|c|c|c|c|c|c|}
\hline ESPÉCIE & ESTADO & MUNICÍPIO & № USP & T. gondii & Neospora. spp. \\
\hline \multirow[t]{20}{*}{ JUMENTOS } & $\begin{array}{c}\text { Rio Grande do } \\
\text { Norte }\end{array}$ & Mossoró & Mo 2 & 64 & $\mathrm{~N}$ \\
\hline & & & Mo 3 & 64 & $\mathrm{~N}$ \\
\hline & & & Mo 4 & 256 & $\mathrm{~N}$ \\
\hline & & & Mo 5 & 64 & $\mathrm{~N}$ \\
\hline & & & Mo 6 & 64 & $\mathrm{~N}$ \\
\hline & & & Mo 7 & 64 & $\mathrm{~N}$ \\
\hline & & & Mo 9 & 256 & $\mathrm{~N}$ \\
\hline & & & Mo 10 & 64 & $\mathrm{~N}$ \\
\hline & Paraíba & Patos & $\mathrm{Pa} 27$ & 64 & $\mathrm{~N}$ \\
\hline & & & $\mathrm{Pa} 31$ & 64 & $\mathrm{~N}$ \\
\hline & & & $\mathrm{Pa} 30$ & 64 & $\mathrm{~N}$ \\
\hline & & & $\mathrm{Pa} 31$ & 64 & $\mathrm{~N}$ \\
\hline & & & $\mathrm{Pa} 37$ & 64 & $\mathrm{~N}$ \\
\hline & & & $\mathrm{Pa} 41$ & 64 & $\mathrm{~N}$ \\
\hline & $\begin{array}{c}\text { Rio Grande do } \\
\text { Norte }\end{array}$ & Mossoró & Mo 44 & 64 & $\mathrm{~N}$ \\
\hline & & & Mo 45 & 256 & $\mathrm{~N}$ \\
\hline & & & Mo 46 & 64 & $\mathrm{~N}$ \\
\hline & & & Mo 49 & 64 & $\mathrm{~N}$ \\
\hline & & & Mo 50 & 256 & $\mathrm{~N}$ \\
\hline & & & Mo 61 & 256 & $\mathrm{~N}$ \\
\hline
\end{tabular}


Pernambuco

\section{Petrolina}

Pe 67

Pe 69

Pe 71

Pe 72

Pe 77

Pe 78

Pe 80

Pe 81

Pe 83

Pe 84

Pe 85

Pe 86

Pe 87

Pe 88

Pe 89

Pe 90

Pe 91

Pe 92

Pe 93

Pe 94

Pe 95

Pe 96

Pe 97

Pe 98

Pe 99

Pe 100

Pe 101
64

64

64

64

64

64

64

256

64

64

64

256

64

64

64

64

256

64

256

256

256

64

64

64

64

64

64
N

N

N

50

N

N

N

N

N

N

N

N

50

100

N

N

$N$

$\mathrm{N}$

N

N

N

N

N

N

N

N

N 


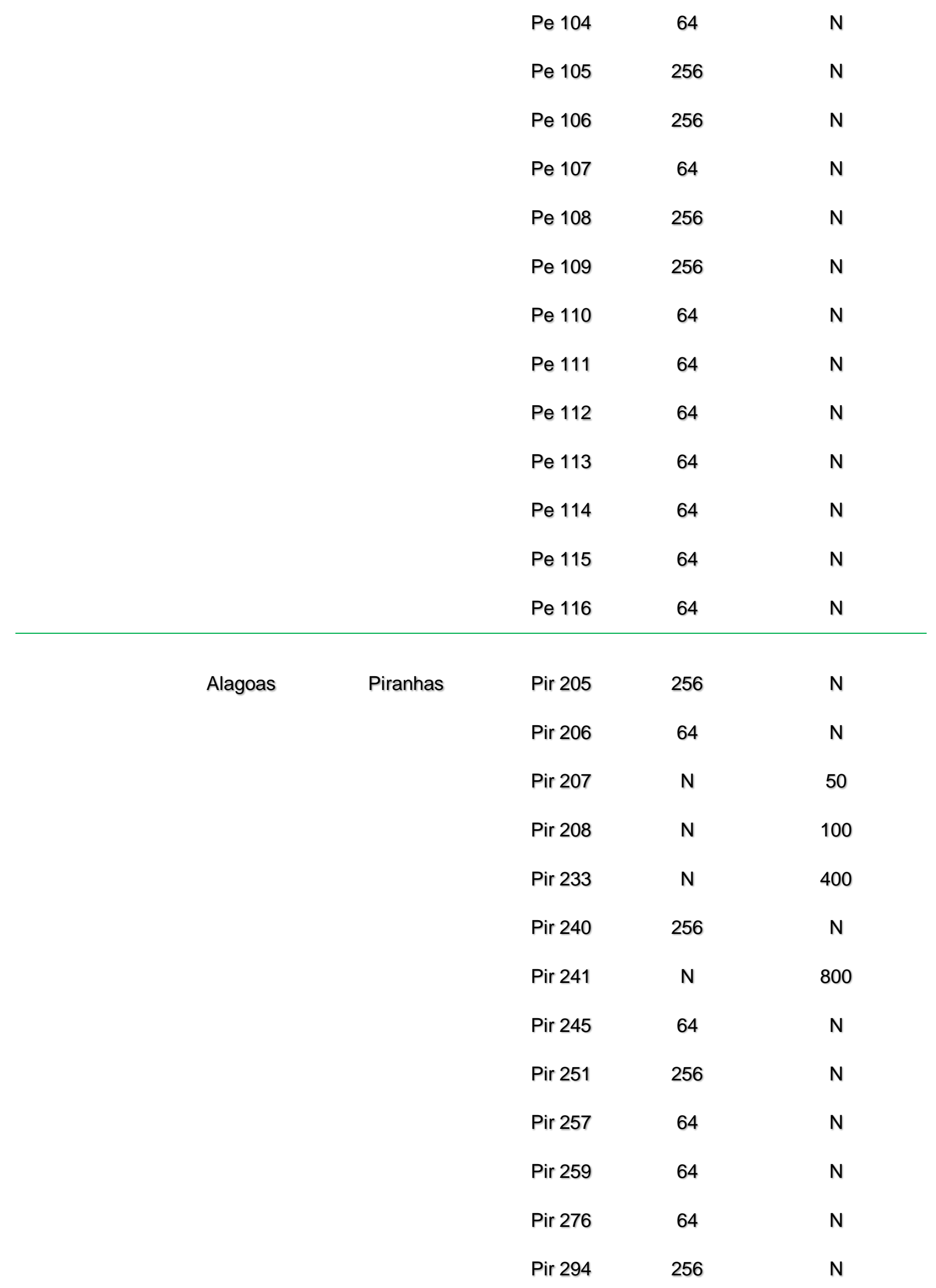




\begin{tabular}{|c|c|c|c|c|c|}
\hline & & & Pir 295 & 256 & $\mathrm{~N}$ \\
\hline & & & Pir 296 & 256 & $\mathrm{~N}$ \\
\hline & & & Pir 297 & 64 & $\mathrm{~N}$ \\
\hline & & & Pir 298 & 256 & $\mathrm{~N}$ \\
\hline & Piauí & Campo Maior & $\mathrm{Cm} 441$ & 64 & $\mathrm{~N}$ \\
\hline & & & $\mathrm{Cm} 443$ & 64 & $\mathrm{~N}$ \\
\hline & & & $\mathrm{Cm} 444$ & 64 & $\mathrm{~N}$ \\
\hline & & & $\mathrm{Cm} 445$ & 64 & $\mathrm{~N}$ \\
\hline & & & $\mathrm{Cm} 446$ & 64 & $\mathrm{~N}$ \\
\hline & & & $\mathrm{Cm} 447$ & 64 & $\mathrm{~N}$ \\
\hline & & & $\mathrm{Cm} 448$ & 64 & $\mathrm{~N}$ \\
\hline & & & $\mathrm{Cm} 449$ & 64 & $\mathrm{~N}$ \\
\hline & & & $\mathrm{Cm} 450$ & 64 & $\mathrm{~N}$ \\
\hline EQUINOS & Pernambuco & Petrolina & Pe 118 & 64 & $\mathrm{~N}$ \\
\hline & & & Pe 119 & 64 & $\mathrm{~N}$ \\
\hline & & & $\mathrm{Pe} 120$ & 256 & $\mathrm{~N}$ \\
\hline & & & $\mathrm{Pe} 121$ & 256 & $\mathrm{~N}$ \\
\hline & & & $\mathrm{Pe} 122$ & 64 & $\mathrm{~N}$ \\
\hline & & & $\mathrm{Pe} 123$ & 64 & $\mathrm{~N}$ \\
\hline & & & Pe 124 & 256 & $\mathrm{~N}$ \\
\hline & & & $\mathrm{Pe} 125$ & 256 & $\mathrm{~N}$ \\
\hline & & & Pe 129 & 64 & $\mathrm{~N}$ \\
\hline & & & Pe 130 & 64 & $\mathrm{~N}$ \\
\hline & & & $\mathrm{Pe} 131$ & $\mathrm{~N}$ & 50 \\
\hline & & & $\mathrm{Pe} 136$ & 256 & $\mathrm{~N}$ \\
\hline & & & $\mathrm{Pe} 138$ & 64 & $\mathrm{~N}$ \\
\hline
\end{tabular}




\begin{tabular}{|c|c|c|c|}
\hline & Pe 139 & 64 & $\mathrm{~N}$ \\
\hline & $\mathrm{Pe} 140$ & 256 & $\mathrm{~N}$ \\
\hline & $\mathrm{Pe} 146$ & 64 & $\mathrm{~N}$ \\
\hline & $\mathrm{Pe} 147$ & 64 & $\mathrm{~N}$ \\
\hline & $\mathrm{Pe} 150$ & 256 & $\mathrm{~N}$ \\
\hline & $\mathrm{Pe} 151$ & 64 & $\mathrm{~N}$ \\
\hline & Pe 152 & 64 & $\mathrm{~N}$ \\
\hline & Pe 153 & 64 & $\mathrm{~N}$ \\
\hline & Pe 154 & 64 & $\mathrm{~N}$ \\
\hline & $\mathrm{Pe}-155$ & 64 & $\mathrm{~N}$ \\
\hline & Ar 379 & 64 & $\mathrm{~N}$ \\
\hline & $\operatorname{Ar} 380$ & 64 & $\mathrm{~N}$ \\
\hline & Ar 381 & 64 & $\mathrm{~N}$ \\
\hline & Ar 382 & 64 & $\mathrm{~N}$ \\
\hline & Ar 383 & 64 & $\mathrm{~N}$ \\
\hline & Ar 384 & 64 & $\mathrm{~N}$ \\
\hline & Ar 385 & 64 & $\mathrm{~N}$ \\
\hline & Ar 386 & 64 & $\mathrm{~N}$ \\
\hline & Ar 387 & 64 & $\mathrm{~N}$ \\
\hline & Ar 388 & 64 & $\mathrm{~N}$ \\
\hline MULAS & Pe 156 & 64 & $\mathrm{~N}$ \\
\hline & Pe 157 & 256 & $\mathrm{~N}$ \\
\hline & Pe 158 & 64 & $\mathrm{~N}$ \\
\hline & Pe 159 & 64 & $\mathrm{~N}$ \\
\hline & $\mathrm{Pe} 160$ & 256 & $\mathrm{~N}$ \\
\hline & $\mathrm{Pe} 161$ & 64 & $\mathrm{~N}$ \\
\hline & Pe 162 & 64 & $\mathrm{~N}$ \\
\hline
\end{tabular}




$\begin{array}{lll}\text { Pe } 163 & 64 & \text { N } \\ \text { Pe } 164 & 64 & \text { N } \\ \text { Pe } 165 & 64 & \text { N } \\ \text { Pe } 166 & 256 & \text { N } \\ \text { Pe } 167 & 256 & \text { N } \\ \text { Pe } 168 & 64 & \text { N } \\ \text { Pe } 169 & 64 & \text { N } \\ \text { Pe } 183 & 64 & \text { N } \\ \text { Pe } 184 & \text { N } & 50\end{array}$

